\title{
Domestic AIDS Vaccine Trials: Addressing the Potential for Social Harm to the Subjects of Human Experiments
}

\author{
Philip A. Leider $\uparrow$
}

In 1998, the FDA approved the first large-scale human trials of a candidate AIDS vaccine in our nation's history. While the legal issues raised by these trials are manifold, the academic literature has focused almost exclusively on the potential for mass tort liability and the resulting hesitancy of biotech and pharmaceutical firms to enter the field. This Comment argues that another issue of vital concern demands attention: the potential for social harm to the human subjects of AIDS vaccine trials. After providing an overview of the current epidemiology of HIV/AIDS and explaining why a safe, effective AIDS vaccine represents the best way to control the pandemic, this Comment analyzes the scientific and social obstacles to production of such a vaccine.

In order to know whether a candidate AIDS vaccine is truly effective, researchers will have to test the product in HIV-negative volunteers at high risk of infection. Since these volunteers may subsequently test positive for HIV on standard blood tests, they will be vulnerable to discrimination on that basis in such areas as employment, insurance, immigration, and

Copyright $\odot 2000$ California Law Review, Inc. California Law Review, Incorporated (CLR) is a California nonprofit corporation. CLR and the authors are solely responsible for the content of their publications.

$\dagger \quad$ Law Clerk to the Honorable Charles A. Legge, District Judge, United States District Court for the Northern District of California (2000-2001), the Honorable Mary M. Schroeder, Circuit Judge, United States Court of Appeals for the Ninth Circuit (2001-2002); J.D., School of Law, University of California, Berkeley (Boalt Hall), 2000; M.A., University of California, Irvine, 1991; B.A., Yale University, 1988. Many thanks to Professors Linda Krieger, Eric Rakowski, Marjorie Shultz, and Associate Dean Eleanor Swift for their support and encourageinent. Thanks also to Susan Buchbinder, Scott Carroll, Chris Collins, Christopher Gates, Ellen LaPointe, Paul O'Malley, Bill Snow, Leslie Wolf, Joe Wright, and the inembers of Vaccine Advocates for helpful observations on earlier drafts of this Comment. To all the members of California Law Review, particularly Matthew Africa, Scott Birkey, Rebecca Engrav, Julia Fromholz, Alistair Newbern, James Oleson, Tracy Phillips and Julie Pietrantoni, I owe a special debt of gratitude. Finally, to iny family and my partner, Tony Buckman, I am grateful beyond words. 
incarceration. Moreover, by participating in vaccine trials, volunteers will be marking themselves as people at high risk of HIV infection, another basis for disparate treatment. Researchers have suggested that federal disability discrimination law may afford protection against research-related social harms. Through close analysis of the Americans with Disabilities Act of 1990 and the Supreme Court's decision in Bragdon v. Abbott, this Comment demonstrates that optimistic reliance on federal disability law is misplaced. The unique issues raised by domestic AIDS vaccine trials must be addressed in their own right. The Comment accordingly concludes with a broad range of legislative and regulatory proposals to protect trial participants and advance the AIDS vaccine research agenda.

\section{INTRODUCTION}

In May of 1998, the U.S. Food and Drug Administration (FDA) granted permission for the first domestic efficacy trial of a preventive AIDS vaccine in our nation's history.' The vaccine, AIDSVAX, has already been tested for safety im over 1,200 human subjects. ${ }^{2}$ In Phase II trials, AIDSVAX proved safe, with no significant side effects, and it induced HIV antibody response im most vaccinated individuals. ${ }^{3}$ Five thousand HIV-negative volunteers in climics across North America, Puerto Rico, and the Netherlands will now offer up their forearms to see if AIDSVAX is not only safe but also effective in preventing HIV infection. ${ }^{4}$

1. See Joan Stephenson, AIDS Vaccine Moves into Phase 3 Trials, 280 JAMA 7 (1998); Alice Park, First AIDS Vaccine: Better Than Nothing, Time, June 13, 1998, at 66; A Shot in the Arm for an AIDS Vaccine, NEwswEEK, June 15, 1998, at 62. Before the FDA will approve a candidate vaccine for trial in humans, it must successfully pass through basic research and developinental processes, oftcn involving cell cultures and preclinical trials in animals. See NATIONAL INSTITUTE OF ALLERGY AND INFECTIOUS DISEASES (NIAID), UNDERSTANDING VACCINES 22 (1998). If approved for testing in humans, the vaccine inust then undergo at least three phases of clinical trials before it can be licenscd for public use. See id. Phase I trials, involving small numbers of human subjects, test the candidate vaccine for safety and optimal dosing. See id. Pliase II trials, open to hundreds of volunteers, determine whether the vaccine is safe and "immonugeinc," that is, whether it stimulates an immune response. Id. at 24. Finally, Phase III efficacy trials, involving thousands of individuals, are used to evaluate whether the vaccine safely prevents disease. See $i d$. "A vaccine is considered successful if its overall effeet is beneficial; it should prevent disease, and any side effects should be minimal." Id. For further discussion of the structure of clinical trials and the unique challenges posed by AIDS vaccine research, see discussion infra Part II.

2. AIDSVAX is produced by VaxGen, a spin-off of Genentech. AIDSVAX is a preparation of recombinant gp120, the glycoprotein from HIV's envelope that binds to the surface of T-cells. The product moving into Phase III trials is actually a bivalent successor to the monovalent gp 120 vaccines tested in Phase II trials. See VaxGen, VaxGen Gains FDA Go-Ahead for First-Ever Phase III Trial of HIV Vaccine; Company to Begin Large-Scale Tests This Month (last modified June 3, 1998) $<$ http://www.vaxgen.com/new/srelease/vaxgen_gains_fda_goahead.htm>.

3. See id.

4. See VaxGen, VaxGen Inoculates 5,000 Volunteers in U.S. Trial of HIV Vaccine (last modified Oct. 12, 1999) <http://www.vaxgen.com/newsrelease/5000\%20inoculated.htm>. VaxGen will be testing a related formulation with 2,500 volunteers in Thailand. See id. 
Although it is a genuine cause for celebration in the battle against AIDS, ${ }^{5}$ the progress to large-scale testing of AIDS vaccines such as AIDSVAX also raises a host of vexing legal issues. What will happen if trial participants have adverse physical reactions to candidate vaccines? Who will pay for their medical care? Should msurance companies have to pay for injuries caused by experimental products? Or should biotechnology companies, like VaxGen, be liable for trial-related injuries? If the latter, are these smaller spin-offs of larger corporations sufficiently capitalized to compensate victims? If they are not, will courts pierce the corporate veil and make larger corporate shareholders, like Genentech, bear the risk? Or should the state subsidize the efforts of companies like VaxGen-those that take risks in the interest of public health-by shielding them from unlimited tort liability and paying victims out of some form of state fund? These and many other questions clustered around injury compensation and tort relief for biotechnology and pharmaceutical coinpanies have dominated the burgeoning legal literature on AIDS vaccine research. ${ }^{6}$

Eclipsed by the potential for mass tort liability, another issue of substantial concern has received scant legal attention thus far: The prospect of social harms facing participants in AIDS vaccine trials. ${ }^{7}$ The AIDSVAX

5. FDA approval of the AIDSVAX trial has elicited a broad range of responses. See, e.g., Michael Balter, Impending AIDS Vaccine Trial Opens Old Wounds, 279 SCIENCE 650 (1998); Philip Cohen, Long Shot: A Milestone in the War on AIDS is also a Sign of Desperation, New ScientisT, June 13, 1998, at 12; Bill Snow, An AIDS Vaccine: How Long Must We Wait?, 353 LANCET 9148 (1999); Peter Wehrwein \& Kelly Morris, HIV-1-Vaccine-Trial Go-Ahead Reawakens Ethics Debate, 351 LANCET 1789 (1998).

6. See, e.g., Deborah M. Barnes, Will an AIDS Vaccine Bankrupt the Company that Makes It?, 233 SCIENCE 1035 (1986); Jon Cohen, Is Liability Slowing AIDS Vaccines?, 256 SCIENCE 168 (1992); Sally-Anne Danner, The Vaccine Ailment: A Cure to Encourage Litigation-Shy Phamaceutical Companies to Manufacture an AIDS Vaccine, 14 HamLINE J. PUB. L. \& PoL'Y 67 (1993); Joseph Earley, Can Biotechnology Immunize Vaccine Manufacturers from the Products Liability Crisis?, 30 JuRImetrics J. 351 (1990); Donald P. Francis \& John C. Petricciani, The Prospects for and Pathways Toward a Vaccine for AIDS, 313 NEw ENG. J. MED. 1586 (1985); Charles F. Hagan, Vaccine Compensation Schemes, 45 Food Drug CoSM. L.J. 477 (1990); Catherine M. Polizzi, A Proposal for a Federal AIDS Immunization Policy, 9 J.L. \& HealTH 1 (1995); John P. Wilson, The Resolution of Legal Impediments to the Manufacture and Administration of an AIDS Vaccine, 34 SANTA CLARA L. Rev. 495 (1994); Alison Joy Arnold, Comment, Developing, Testing, and Marketing an AIDS Vaccine: Legal Concerns for Manufacturers, 139 U. PA. L. REv. 1077 (1991); Kelley E. Cash, Note, The New Restatement (Third) of Torts: Is it the Cure for the AlDS Vaccine Ailment?, 16 REv. LITIG. 413 (1997); Kellen F. Cloney, Note, AIDS Vaccine Manufacturers v. Tort Regime: The Need for Alternatives, 49 WASH. \& LEE L. REv. 559 (1992); Robert M. McKenna, Comment, The Impact of Product Liability Law on the Development of a Vaccine Against the AIDS Virus, 55 U. CHI. L. REv. 943 (1988); H. William Smith III, Note, Vaccinating AIDS Vaccine Manufacturers Against Product Liability, 42 CASE W. RES. L. REv. 207 (1992).

7. Although the legal community has been slow to awaken to it, researchers and AIDS activists have foreseen the problem of vaccine trial participants being subjected to social harms. See, e.g.,

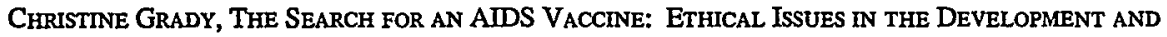
Testing of a Preventive HIV Vaccine 141-42 (1995); Chris Collins, Sustaining Support for

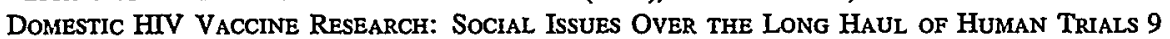
(Center for AIDS Prevention Studies, Univ. of Cal. San Francisco, Monograph Series, Occasional 
trial serves as a good illustration: In Phase $\Pi$ trials of the product, $95.5 \%$ of vaccinated individuals generated HIV antibody responses. ${ }^{8}$ Because standard blood tests for HIV detect the presence of HIV antibodies, it is possible, if not probable, that many of these individuals will test positive for HIV even though they are not actually infected.' What will happen if these trial participants test positive for HIV when they apply for health insurance or for a job? How will employers, prison officials, customs officers, and others who rely on medical information regard a positive ELISA test? ${ }^{10}$ If they react negatively, should trial participants reveal that they are taking part in an AIDS vaccine trial? ${ }^{11}$ Since AIDS vaccine trials are widely publicized as enrolling only "high-risk individuals" (for example, gay men, prostitutes, and injection drug users), does revealing trial participation simply substitute one potential basis of disparate treatment for another? Finally, who would enroll in an AIDS vaccine trial given the evident physical and social risks, and how, as a result, will five thousand volunteers for the Phase III trial of each candidate vaccine be assembled?

This Comment addresses the concerns outlined above by advancing a four-fold thesis: (1) the world needs a safe, effective preventive vaccine to curb the global AIDS epidemic; (2) production of such a vaccine will

Paper \#2, 1996); Beryl A. Koblin et al., Readiness of High-Risk Populations in the HIV Network for Prevention Trials to Participate in HIV Vaccine Efficacy Trials in the United States, 12 AIDS 785 (1998); Amy R. Sheon et al., Preventing Discrimination Against Volunteers in Prophylactic HIV Vaccine Trials: Lessons from a Phase II Trial, 19 J. AcQuired Immune Deficiency Syndromes \& Hum. RETROVIROLOGY 519 (1998).

8. See VaxGen, supra note 2.

9. The ELISA, or enzyme-linked immunosorbent assay, is a blood test that detects the presence of antibodies to HIV in the blood. See NIAID, HIV Vaccine Glossary (visited Apr. 3, 2000) $<$ http://www.niaid.nih.gov/factsheets/GLOSSARY.htm> (defining "ELISA"). It is commonly used as an initial screening test for HIV because it is "relatively easy and inexpensive to perform." Id. Because the ELISA test often registers false positive results, identifying antibodies where there are none, it is usually confirmed by "a second, more specific test such as an HIV Western Blot." Id.

One problem in AIDS vaccine trials is that standard assays do not readily distinguish HIV antibodies from vaccine-induced antibodies. As NIAID explains,

[w] hen people develop antibodies to HIV or an experimental HIV vaccine, they

"seroconvert" from antibody-negative to antibody-positive. Vaccine-induced seroconversion

does not represent an infection. Instead, vaccine-induced seroconversion is an expected response to vaccination that may disappear over time.

Id. (defining "seroconversion"). Thus, even though researchers "expect" vaccine-induced seroconversion, standard blood tests inay not register a difference between infection and vaccination. As a result, researcbers can anticipate and test for vaccine-induced antibodies using specialized tests, while the general public imight easily confuse vaccination with HIV infection. For a helpful overview of currently available blood assays and their relative advantages and disadvantages, see Niel Constantine, HIV Antibody Testing (last modified Feb. 1998) <http://hivinsite.ucsf.edu/akb/1997/02abtest/index.html>.

10. See discussion infra Part III.A.

11. Due to the double-blind structure of vaccine trials, discussed infra Part II.D, participants will not be informed whether they have received vaccine or placebo. As a result, they will not readily know whether they have actually seroconverted or are simply reacting to vaccine. As discussed infra Part III.A, researchers are offering on-site testing and participant ID cards as possible responses to this problem. 
take place only if human subjects are reasonably safeguarded against physical and social harm; (3) extant legal and regulatory protections will not suffice to minimize trial-related social harms, and, correlatively, this will adversely affect trial enrollment in the long-term; and (4) appropriate federal measnres should be taken to protect research subjects and enhance the prospects for a successful AIDS vaccine.

The Comment is divided imto five Parts. Part I provides an overview of the current epidemiology of AIDS. After fleshing out why the treatment options currently available will not suffice to curb the global AIDS epidemic, Part I outlines the rationale behind preventive intervention and the considerable advantages a safe, effective AIDS vaccine could provide.

Part II discusses the basic scientific obstacles to AIDS vaccine research that make the participation of human subjects at high risk of infection essential to determiming the efficacy of a candidate vaccine. Since individuals at high risk of infection are often also socially vulnerable, Part II links the scientific barriers facing AIDS vaccine research to the social impediments at the core of the Comment's analysis.

Part III focuses on the specter of social harms to human subjects in domestic AIDS vaccine trials. Since candidate vaccines may make volunteers test positive for HIV on standard assays, ${ }^{12}$ trial participants will be made vulnerable to the various forms of discrimination facing HIVpositive people today. In addition, AIDS vaccine trial participants will be marking theinselves as members of a "high-risk group" since the entry criteria for vaccine trials will necessarily focus on risk behavior such as anal sex or injection drug use. ${ }^{13}$ Research subjects will accordingly face disparate treatment on at least two grounds: Their apparent HIV-positive serostatus and their membership im a group at high risk of exposure to the AIDS virus. Without some form of ex ante legal protection, potential human subjects will be exposed to considerable prospective harm and, as a result, will be discouraged from participating in clinical vaccine trials.

Part IV begims this Comment's analysis of potential sources of legal protection for AIDS vaccine trial participants by focusing on the Americans with Disabilities Act of $1990^{14}$ (hereinafter "ADA" or "the Act"). Part IV evaluates whether AIDS vaccine trial participants who falsely test positive for HIV will be protected by the ADA, as researchers have optimistically suggested. It concludes that ADA jurisprudence is not sufficiently settled to answer the question defimitively. It further illustrates that disability law is, at best, an awkward fit for trial subjects. Part IV therefore underscores the need for a legislative and regulatory regime umiquely tailored to large-scale vaccine trials.

12. See discussion infra Part III.A.

13. See discussion infra Part III.B.

14. 42 U.S.C. $\$ \S 12101-12213$ (1994). 
Part V proposes a series of federal legislative and regulatory measures to address the problem of social harms to ADS vaccine trial participants. These measures must take stock of the existing patchwork of regulations and procedural controls, such as the role of Institutional Review Boards in the design and oversight of study protocols, that could be enhanced. In addition, the proposed measures must be coordinated with related measures, such as limited tort relief for biotechnology and pharmaceutical companies and an indemnification fund for trial-related injuries, to give the U.S. a coherent, effective AIDS vaccime policy.

\section{I}

\section{The NeEd For AN AIDS VACCINE}

\section{A. Current State of the AIDS Epidemic}

It is customary to begin any discussion of ADS vaccine research with what one report aptly calls "a recapitulation of the latest epidemiological horrors." 15 The latest global statistics are indeed grim. Estimates by the Joint United Nations Programme on HIVIAIDS (UNAIDS) and the World Health Organization (WHO) mdicate that 16.3 million people around the world have died of Acquired Immune Deficiency Syndrome (AIDS) since the beginning of the epidemic. ${ }^{16}$ By the end of 1998 , over 33.6 million people were living with Human Immunodeficiency Virus (HIV), the virus that causes AIDS. ${ }^{17}$ In addition, an estimated 5.6 million people worldwide were newly infected with HIV in $1999 .^{18}$

In sharp contrast to the rest of the world, Western nations have experienced a rapid decline in ADS cases. ${ }^{19}$ The draniatic turnaround can be attributed in large measure to remarkable advances in the therapeutic treatment of HIV. Most notable among these advances has been the advent

15. AIDS Vaccine AdVocacy CoALITION (AVAC), INDUSTRY INVESTMENT IN HIV VacCiNe RESEARCH: AN INVESTIGATION BY THE AIDS VACCINE ADVOCACY COALITION 7 (1996).

16. See UNAIDS \& WHO, AIDS EPIDEMIC UPDATE: DECEMBER 1999, at 2 (1999).

17. See id.

18. See id.

19. Western Europe, for example, recorded a 38\% drop in AIDS cases from 1995 to 1997. See UNAIDS \& WHO, Report on the Global HIV/AIDS Epidemic June 1998: The Evolving Picture Region by Region (last modified June 1998) <http://www.unaids.org/hivaidsinfo/statistics/ june98/global\%5Freport/rep_html/report3.html>. In the United States, AIDS-related death rates declined 47\% from 1996 to 1997, and AIDS fell from eighth to fourteenth among leading causes of death in the U.S. over the same time period. See U.S. Department of Health and Human Services (HHS), AIDS falls from Top Ten Causes of Death; Teen Births, Infant Mortality, Homicide All Decline (last modified Oct. 7, 1998) <http://www.cdc.gov/nchs/releases/98news/98news/aidsmort.htm>. The successes, however, have not been uniform. While cases of AIDS have dramatically decreased among white gay and bisexual men in the West, communities of color, women, and gay youth have seen disturbing increases in rates of infection. See MAPPING THE AIDS PANDEMIC (MAP) NETWORK, Provisional Report: The Status aNd TRENDS OF THE HIV/AIDS EPIDEMICS IN THE WORLd 7 (1998); see also The WhIte House, The National AIDS Strategy 8 (1997) [hereinafter NationaL AIDS STRATEGY]. 
of protease inhibitors and so-called "combination" or "triple cocktail" therapy. ${ }^{20}$ However, these treatment regimens are expensive and difficult to adhere to; the drugs often require refrigeration and they can cause toxic side-effects in HIV-infected individuals. As a result, developing countries, where the AIDS pandeinic is spreading uncontrollably and the infrastructure to deliver medication is largely non-existent, have not appreciably benefited from the latest advances. ${ }^{21}$ The result is as predictable as it is lamentable: Western nations are generally seeing a steep decline in the rate of ADS-related deaths (accompanied by a large increase in the number of people living with HIV), while in developing countries both infection and mortality rates contimue to climb precipitously. ${ }^{22}$

\section{B. Recent Advances Do Not Eliminate the Need for Preventive Intervention}

It is important to recapitulate the "latest epidemiological horrors," then, for at least four reasons. First, the media have loudly trumpeted recent advances in ADS treatment. ${ }^{23}$ Anecdotal evidence suggests that people who hear of these advances are increasingly engaging in risky behavior, presumably because fear of disease is on the decline. ${ }^{24}$ In other

20. See generally Charles C.J. Carpenter et al., Antiretroviral Therapy for HIV Infection in 1998: Updated Recommendations of the International AIDS Society-USA Panel, 280 JAMA 78 (1998); Oren J. Cohen \& Anthony S. Fauci, HIV/AIDS in 1998-Gaining the Upper Hand?, 280 JAMA 87 (1998); Steven G. Deeks et al., HIV-1 Protease Inhibitors: A Review for Clinicians, 277 JAMA 145 (1997). For regularly updated treatment guidelines for people living with HIV/AIDS, see Panel on Clinical Practices for the Treatment of HIV Infection, Guidelines for the Use of Antiretroviral Agents in HIV-Infected Adults and Adolescents (last modified Jan. 28, 2000) <http://www.hivatis.org/trtgdhıs.html>.

21. The situation in southern Africa is particularly stark. According to UNAIDS and WHO estimates, seven out of ten people who became infected with HIV in 1998 live in sub-Saharan Africa. Among children under fifteen years of age, the proportion is nine out of ten. Of all AIDS deaths since the epidemic began in 1981, 83\% have occurred in sub-Saharan Africa. Only one-tenth of the world's population, however, lives in Africa south of the Sahara. See UNAIDS, AIDS in Africa (last modified Nov. 30, 1998) <http://www.unaids.org/publications/documents/epidemiology/determinants/saepap98. $\mathrm{html}>$. Needless to say, antiretroviral therapy reginens have not yet had an impact in sub-Saharan Africa.

22. See MAP NETWORK, supra note 19 , at 7 .

23. Egregious examples of media hype abound. See, e.g., Carl T. Hall, How Wonder Drugs Give New Life, S.F. CHRON., Mar. 10, 1997, at E1 ("the newfangled pills known as protease inhibitors are about as close as you can get to a wonder drug for AIDS"); Chris Kraul, Agouron's 'Magic Bullet': HIV Drug Stirs Interest of Doctors, Investors, L.A. TIMES, Jan. 29, 1997, at D2 (touting Viracept as a "Inagic bullet drug" prior to FDA approval); Michael Waldholz, Strong Medicine: New Drug 'Cocktails' Mark Exciting Tum In the War on AIDS-Companies Race to Market With 'Protease Inhibitors' After Good Test Results-'I Feel Wonderful, Incredible', WALL ST. J., June 14, 1996, at A1 (suggestimg that scientists "may finally have cornered the long-elusive virus" with cocktail therapies). See generally Jon Cohen, The Media's Love Affair With AIDS Research: Hope vs. Hype, 275 SCIENCE 298 (1997) (reporting researchers' fears that media coverage of AIDS treatments crosses the line separating hope from hype).

24. "Barebacking," that is, engaging in anal sex without a condom, is reportedly on the rise among gay men. See, e.g., Robert B. Hays et al., High HIV Risk-Taking Among Young Gay Men, 4 
words, as people come to regard HIV as a treatable disorder, their fear of infecting others or getting infected themselves may correspondingly decrease. ${ }^{25}$ Needless to say, current HIV prevention efforts will founder if safer-sex and clean-needle campaigns must constantly counterspin misleading media coverage of advances in AIDS treatment. The irony is patent: Advances in AIDS treatment may increase, to some degree, the incidence of HIV infection. ${ }^{26}$

Second, while treatment efforts have shown remarkable success in industrialized countries, there has been little headway in developing countries. The success of new treatinents has virtually blinded people in Western countries to the continuing ravages of the pandemic elsewhere in the world: Their frame of reference no longer includes the unchecked progression of disease still so prevalent "over there." 27 Since the resources to combat the disease remain largely in Western hands, awareness of the epidemic's worldwide effects remains a vital counponent of AIDS advocacy and political lobbying efforts (for example, to increase availability of antiretroviral therapies in developing countries or sustain domestic research

AIDS 901 (1990); Charles Petit, New HIV Drugs Give Some S.F. Gays Excuse for Risky Sex, Poll Says, S.F. Chron., Aug. 14, 1997, at A14; Marc Peyser, A Deadly Dance, Newsweek, Sept. 29, 1997, at 76.

25. See generally Jeffrey A. Kelly et al., Protease Inhibitor Combination Therapies and Perceptions of Gay Men Regarding AIDS Severity and the Need to Maintain Safer Sex, 12 AIDS F91 (1998) (finding that a substantial number of individuals believe AIDS is now nearly cured and concluding that it is necessary to temper the optimism regarding treatment advances); S. Murphy et al., Antiretroviral Drugs and Sexual Behavior in Gay and Bisexual Men: When Optimism Enhances Risk, 12 INT'L CONF. AIDS 209 (1998) (conclnding that individuals engaging in risky sex are cither rationalizing their behavior through optimism about the effectiveness of treatments or arc actually less concerned about contracting or transmitting HIV); J. Toeppich ct al., Does Safer Sex Survive the Therapeutic Optimism in the General Public?, 12 INT'L CoNF. AIDS 947 (1998) (reviewing comparative historical data drawn from questions posed during the German national AIDS prevention campaign).

26. See Robin A. Weiss, AIDS: Will Therapy Spread Disease?, 350 NATURE 276, 276 (1991) (noting that "the longer life-span gained from drug treatment also provides an infectious person more opportunities to spread HIV to others"); see also ThOMAS J. PHILIPSON \& RICHARD A. PosnER, Private Choices and Public Health: The AIDS Epidemic in an Economic Perspective 187 (1993) (arguing that effective AIDS treatments "reduce the expected costs of the disease to potential victims and by so doing increase the amount of risky sex"). But see William N. Eskridge, Jr. \& Brian D. Weimer, The Economics Epidemic in an AIDS Perspective, 6 U. CHI. L. Rev. 733, 734 (1994) (book review) (critiquing Philipson and Posner's rational behavioral model as "insufficiently coinplex" to account for most events that transmit HIV).

27. The UNAIDS HIV Drug Access Initiative commenced in late 1997. It aims to make HIVrelated drugs more accessible to broad scctors of populations in developing countries. The Initiative has begun pilot-testing of antiretroviral therapies in Chile, Vietnam, Uganda, and the Côte d'Ivoire. See UNAIDS, UNAIDS Launches Initiative to Help Bridge Gap in Access to HIV/AIDS-Related Drugs in Developing World: Multinational Pharmaceutical Companies Already Committed to Making Drugs More Affordable (last modified Nov. 5, 1997) <http://www.unaids.org/whatsnew/press/eng/ pressarc97/drug.html $>$. Organizations such as the International AIDS Vaccine Initiative (IAVI), the AIDS Vaccine Advocacy Coalition (AVAC), the American Foundation for AIDS Research (amfAR), and the Elizabeth Glaser Pediatric AIDS Foundation (PAF) are also striving to keep the global nature of the epidemic squarely before philanthropic and governmental bodies. See AVAC, ErGHT YEARS AND Counting: What Will Speed Development of aN AIDS VAccine? 47-51 (1999). 
for an AIDS vaccine) ${ }^{28}$ Successful vaccine efforts in the past, such as those for polio and sinallpox, have originated in Western countries; ${ }^{29}$ it is therefore crucial that the citizens of these countries maintain an undistorted understanding of the pandemic's scope so as to spur further research.

Third, although current treatment options may help to stave off progression to disease, they do not do so uniformly. Many people cannot adhere to the exactimg regimen of pills and diet involved; ${ }^{30}$ others do not respond well to the medication; ${ }^{31}$ some have even developed drug-resistant strains of the virus. ${ }^{32}$ And even with perfect compliance, none of the current antiretroviral therapy regimens has proven to be completely effective against the disease. More significantly, the treatments are largely unavailable in developing countries. ${ }^{33}$ It remains to be seen whether treatments developed in the West will prove as effective against other "clades" or genetic subtypes of the virus more prevalent in other parts of the world. ${ }^{34}$ Moreover, given HIV's unfortunate ability to mutate, new strains of the virus are likely to emerge and familiar strains may themselves eventually become resistant to medication. ${ }^{35}$ In short, the long-term prospects for today's promising treatment regimens remain, as yet, uncertain.

Fourth and finally, although decreases in domestic mortality rates are a genuine cause for optimism, the great expense of caring for people living with HIV/AIDS vastly mcreases as more people survive for longer periods of time..$^{36}$ While wealthy nations such as the U.S. may be able to sustain the

28. See Collins, supra note 7, at 4-5; Ronald J. Saldarini, For Vaccines, the Future is Now, 4 NATURE MED. 485, 485-87 (1998).

29. See generally FranK Fenner et al., SMallpox AND ITS ERAdication (1988); Susan L. Plotkin \& Stanley A. Plotkin, A Short History of Vaccination, in VAccnNEs 1,1-11 (Stanley A. Plotkin \& Edward A. Mortimer eds, 1994); Barry R. Bloom \& Roy Widdus, Vaccine Visions and Their Global Impact, 4 NATURE MED. 480,480-84 (1998); Ciro A. de Quadros et al., Eradication of Poliomyelitis: Progress for the Americas, 10 PEdiatric Infectrous Disease J. 222, 222-29 (1991).

30. See R. Chow et al., Medication Use Pattems in HIV-Positive Patients, 46 CAN. J. HospITAL Pharmacy 171, 171-75 (1993); J. A. Lieberman III, Compliance Issues in Primary Care, 57 J. CLIN. PsYCH. 76, 76-82 (1996).

31. The side effects of the various antiretroviral drugs are meticulously catalogued by Drs. Paul Volberding and Steven G. Deeks in Antiretroviral Therapy for HIV Disease (last modified Sept. 1999) <http://www.hivinsite.ucsf.edu/akb/1997/04arvrx/index.html>.

32. See David Perlman, AIDS Discovery Worries Scientists: S.F. Man Infected with DrugResistant Strain of HIV, S.F. CHRON, July 1, 1998, at A1. See generally Martin S. Hirsch et al., Antiretroviral Drug Resistance Testing in Adults with HIV Infection, 279 JAMA 1984 (1998) (reviewing the biology and clinical imphications of HIV resistance to antiretroviral drugs).

33. See discussion supra Part I.A.

34. See aIDS action Foundation, hiV Preventive Vaccines: Social, Ethical and POLITICAL CONSIDERATIONS FOR DOMESTIC EFFICACY TRIALS 5 (1994); IAVI, SUMMARY REPORT AND Recommendations: HIV Vaccines-Accelerating the Development of Preventive hIV VACCINES FOR THE WORLD 9 (1994).

35. See Hirsch et al., supra note 32 , at 1984-85.

36. The drugs for the combimation therapy cocktail alone cost $\$ 10,000$ to $\$ 15,000$ annually, and most HIV/AIDS patients require several other drugs as well. See Linda C. Fentiman AIDS as a Chronic Illness: A Cautionary Tale for the End of the Twentieth Century, 61 AlB. L. Rev. 989, 1004 
heavy economic burden imposed by chronic AIDS care, ${ }^{37}$ other economies cannot absorb the crushing expense. ${ }^{38}$ In countries where famine and other fatal diseases pose imminent threats to the population, paying the high price required for AIDS treatments is difficult to rationalize. Even in wealthier countries, AIDS threatens to overwhelm well-funded public health systems both logistically and financially ${ }^{39}$ Briefly put, the massive expense of AIDS treatment militates for a viable preventive option..$^{40}$

In sum, therapeutic treatment of the AIDS virus, though promising, will not do the job alone. As AIDS treatments progress, people might be more likely to become infected with HIV due to a concomitant decrease in the fear of AIDS. In addition, current treatment regimens are difficult to comply with, and their long-term efficacy is still in question. Even if combination therapy were completely effective, it remains an option open only to industrialized nations at this point. Antiretroviral medications have toxic side-effects $\mathrm{m}$ some infected individuals, they are difficult to preserve in transport, and it is far from certain that they will prove effective against variant strains of the virus. They are also prohibitively expensive for most countries, the infrastructure is not im place to deliver them or monitor their effects, and there are cultural divides that inake compliance with the rigorous regimen involved highly challenging. All of these factors limit the global impact of promising new AIDS therapies. Treatment of AIDS must be supplemented with effective strategies to prevent infection with HIV in the first instance.

(1998); see also NATIONAL AIDS Strategy, supra note 19, at 9 ("The average lifetime cost of medical care after an HIV diagnosis is $\$ 119,000 . ")$.

37. In fiscal year 1998, total federal HIV/AIDS spending was estimated to be $\$ 8.7$ billion. This includes amounts for programs specifically targeted to HIV/AIDS, as well as amounts designated by federal agencies as HIVIAIDS spending within more general activities. Compared to total federal spending, estimated to be $\$ 1.8$ trillion, funding for HIV/ADS represcnts approximately one half of one percent of total federal spending. See Scott Foster et al., Federal HIV/AIDS Spending: A Budget Chartbook (visited Mar. 26, 2000) <http://www.hivinsite.ucsf.edu/social/kaiscr_family_found/ 2098.3d3f.html.

38. See NATIONAL AIDS STRATEGY, supra note 19, at 29; Fentiman, supra note 36, at 1005; Naomi Freundlich et al., AIDS: Hope is Where the Money is, BusINESS WEEK, July 22, 1996, at 34.

39. "Companies in hard-hit countries are losing trained staff at rates unheard of in the industrialized world. Extra staff are hired in anticipation of workforee losses to AIDS. Profits are eaten up by health care costs and work-hours lost to illness and attendance at funcrals." UNAIDS, UNAIDS Executive Director Warns of Unprecedented Emergency in Southern Africa (quoting Dr. Peter Piot, UNAIDS Executive Director) (last modified Nov. 30, 1998) <http://www.unaids.org/whatsnew/ press/eng/pressarc98e.html>.

40. See Report of the Presidential Commission on the Human Immunodeficiency Virus EPIDEMIC 73 (1988) [heremafter REPORT]; Charles Marwick, HIV/AIDS Care Calls for Reallocation of Resources, 279 JAMA 491 (1998). But see Daniel J. DeNoon, Gallo: Too Soon to Focus Solely on AIDS Vaccine, AIDS WEEKLY PLUS, Sept. 7, 1998, at 1. 


\section{The Goal: A Safe and Effective AIDS Vaccine}

As the dimensions of the AIDS pandemic continue to expand, a growing international cadre of scientific, political, and philanthropic organizations and leaders is calling for the production of a safe and effective preventive vaccine against the disease. ${ }^{41}$ Citing the global eradication of smallpox and poliomyelitis as precedents, they argue that an AIDS vaccine is the only coinprehensive way to stem the epidemic worldwide.

A vaccine is "a substance used to teach the immune system how to defend itself against a pathogen, such as a disease-causing virus or other organism." ${ }^{42}$ Deliverable in various ways, a vaccime helps the body to resist infection or progression to disease: "If a vaccine is administered before the body's exposure to a pathogen, it can help the body to completely rid itself of the pathogen or to at least control the pathogen enough to prevent the development of clinical manifestations of disease and to hinder transmission." ${ }^{\text {"43 }}$ A safe and effective HIV vaccine ideally would "be inexpensive to manufacture, provide protection against all subtypes of $\mathrm{HIV}$, require minimal if any boost, protect against all methods of spread of HIV for years, and be easily administered, stable to heat, and widely accessible." ${ }^{\prime 4}$ Even if the "ideal" AIDS vaccine cannot be created, though, a substantially protective vaccine will accomplish inuch.

Vaccines present considerable advantages over established nodes of HIV prevention such as: (1) risk-reduction counseling, which seeks to help people alter their high-risk behaviors; (2) explicit safer-sex education programs; (3) condom distribution; and (4) provision of sterilized needles to mjection drug users. Each of these prevention techniques has disadvantages that reduce its efficacy. Counseling and education prograins rely on genuine behavioral change, which is notoriously difficult to achieve and sustain over time. ${ }^{45}$ Condoms break, and for reasons ranging

41. See President Clinton's remarks, infra note 220; Michael Balter, New Czar Aims to Sharpen France's Effort, 282 SCIENCE 1799, 1799 (1998); Terese Hudson, AIDS Czarina: Clinton's Policy Chief Contends with Spending Caps and Stubborn Myths, 72 Hospitals \& Health Networks 26, 26 (1998); Joan Stephenson, US AIDS Research Office Chief: Intensifying Vaccine, Prevention Research, 280 JAMA 1211, 1211-13 (1998); Victor Zonana, Commonwealth Leaders Urge Greater Support for AIDS Vaccines, IAVI REPORT, Nov.-Dec. 1999, at 5.

42. Encyclopedia of AIDS: A Social, Political, Cultural, and Scientific Record of THE HIV EPIDEMIC 533 (Raymond A. Smith ed., 1998) [hereinafter ENCYCLOPEDIA OF AIDS].

43. Id. Researchers distinguish between preventive vaccines (those that help the body prevent or resist infeetion with $\mathrm{HIV}$, the virus that causes AIDS) and therapeutic vaccines (those that inhibit progression to AIDS once an individual is already infected with the virus). See NIAID, supra note 9 (defining "preventive vaccine" and "therapeutic vaccine"). Throughout this Comment, I use the term "AIDS vaccine" to mean a vaccine aimed at preventing infcction by HIV unless otherwise indicated.

44. Margaret I. Johnston \& Sam Avrett, Developing HIV Vaccines and Other Interventions to Prevent AIDS Worldwide, in TextBook of AIDS Medicine 725, 728 (Thomas C. Merigan, Jr. et al. eds., 1998).

45. See, e.g., S. Maurice Adib et al., Relapse in Sexual Behavior Among Homosexual Men: A 2-Year Follow-Up from the Chicago MACS/CCS, 5 ADS 757 (1991); Marshall H. Becker \& Jill G. 
from physical discomfort to religious objection, people resist using them ${ }^{46}$ Although sterilized needle campaigns have proven successful in reducing rates of HIV transmission among injection drug users, political and moral resistance to needle distribution has thrown up seemingly insurmountable roadblocks in this area. ${ }^{47}$ In short, current modes of HIV prevention, though assuredly a step in the right direction, have failed to contain the epidemic. ${ }^{48}$

It is easy to see why a safe, effective vaccine presents an attractive alternative. Once inoculated, an individual would not have to completely alter long-engramed patterns of behavior to remain protected. Nor would lapses into risk behavior or barrier failures represent the threat they now do; an effective vaccine would offer a second layer of protection. A vaccine would also obviate, to some degree, making clean needles available to injection drug users, a campaign that has drawn vociferous opposition from those who see it as an encouragement to use drugs. Fimally, many of the drawbacks to AIDS treatments, including prohibitive expense, compliance issues, toxicity, and viral resistance, would be eliminated for a large number of imdividuals who might otherwise become infected. Production and dissemination of a safe, effective vaccine against HIV would be the ideal preventive measure in the fight agamst AIDS.

An AIDS vaccime will not, however, magically spring from a test tube like Venus from the foam. The obstacles to discovery, production, and dissemination of a vaccine are formidable, if not insurmountable. Because the design of AIDS vaccine trials raises novel and important issues, I will briefly describe the basic scientific obstacles facing researchers before

Joseph, AIDS and Behavioral Change to Reduce Risk: A Review, 78 AM. J. PUB. HEALTH 394 (1988); Jeffrey A. Kelly et al., Predictors of Vulnerability to AIDS Risk Behavior Relapse, 59 J. ConsultiNG \& CLIN. PsYCH. 163 (1991); Jane McKusher et al., Maintenance of Behavioral Change in a Cohort of Homosexually Active Men, 6 AIDS 861 (1992);M.C. Samuel et al., Changes in Sexual Practices over 5 Years of Follow-Up Among Heterosexual Men in San Francisco, 4 J. ACQUIREd IMMUNe DefiCiBNCY SYNDROMES 896 (1991).

46. See Religion: Conflict over Condoms and AIDS Education for Young People, in THE SociaL IMPACT OF AIDS IN THE UNITED STATEs 292, 292-95 (Albert R. Jonsen \& Jeff Stryker eds., 1993); Study Debunks Theory that Condoms Promote Teen Sex, 12 AIDS PoL'Y \& L. 11, 11 (1997).

47. See School of Public Health, University of California, Berkeley and Institute for Health Policy Studies, University of California, San Francisco, The Public Health Impact of Needle Exchange Programs in the United States and Abroad iii-iv (Sept 1993) (finding that needle-exchange programs are inexpensive to run, are associated with decreases in HIVrisk behavior in injection drug users, and do not contribute to incrcased overall drug use); Gerry V. Stimson, et al., Distributing Sterile Needles and Syringes to People Who Inject Drugs: The SyringeExchange Experiment, in AIDS and Drug Misuse: The Challenges for Policy and Practice in THE I990S 222 (John Strang \& Gerry V. Stimson eds., 1990); Larry Gostin, The Interconnected Epidemics of Drug Dependency and AIDS, 26 HaRv. C.R.-C.L. L. Rev. 113, 147-62 (1991).

48. Targeted intervention has helped decrease infection rates in the gay community, once considered the epicenter of the epidemic. The global trend towards heterosexual and IV drug transmission, though, has fast outstripped any gains in targeted communities. See discussion supra notc 19 and accompanying text. 
turning to the legal and political hurdles facing AIDS vaccine research more generally.

II

\section{SCIENTIFIC ObSTACles to AIDS VACCINE Research AND THEIR EFFECT ON TRIAL DESIGN}

\section{A. The Unique Challenges of AIDS Research}

Although vaccine science flowered in the twentieth century, HIV/AIDS poses unique challenges to vaccine researchers. In the early years of the AIDS epidemic, isolation of the causative agent and identification of the pathways to infection were the paramount issues for scientists. ${ }^{49}$ Public uncertainty and fear about the causes and contagiousness of the disease were widespread; rumors of a "gay pneumonia" hit the newspapers, ${ }^{50}$ and AIDS was treated as what one court has called "the modern day equivalent of leprosy." Simce the underlying immunosuppressive disease was made visible only by the various opportunistic infections that set in-Kaposi's Sarcoma (KS) lesions, candidiasis (thrush), and the rattling cough of pneumocystis carinii pneumonia (PCP)-people saw the lethal effects of infection and remained extremely cautious about even casual contact with those infected. ${ }^{52}$

Once HIV was isolated as the etiologic agent that causes $\mathrm{AIDS}^{53}$ and the principal modes of commumication of the virus were identified, many other advances followed. The first test for HIV was soon available, ${ }^{54}$

49. See generally Anthony S. Fauci, The Human Immunodeficiency Virus: Infectivity and Mechanisms of Pathogenesis, 239 SCIENCE 617 (1988) (discussing HIV as the causative agent of AIDS and sexual, blood, and perinatal contacts as the primary pathways to infection).

50. Randy Shilts, And the Band Played On: Politics, Peorle and the AIDS Epidemic 72 (1987).

51. South Florida Blood Serv. v. Rasınussen, 467 So. 2d 798, 802 (Fla. Dist. Ct. App. 1985). See generally THE SOCIAL IMPACT OF AIDS IN THE UNITED STATES, supra note 46, at 90-97 (sketching the history of the first decade of the epidemic).

52. Recent studies show that so-called "AIDS hysteria" has not significantly abated in the gcneral public. See JoNI N. GRAY ET AL., ETHICAL AND LEGAL IssuES IN AIDS ResearCh 164 (1995) (discussing some of the persistent American myths about the contagiousness of HIV/AIDS); Michael L. Closen, The Decade of Supreme Court Avoidance of AIDS: Denial of Certiorari in HIV-AIDS Cases and its Adverse Effects on Human Rights, 61 ALB. L. Rev. 897, 919 (1998) (arguing that the Supreme Court's refusal to hear HIV/ADS cases in the preceding decade was itself a product of fear of the disease).

53. HIV was isolated nearly simultaneously by three researchers, Dr. Robert Gallo (Bethesda), Dr. Luc Montagnier (Paris), and Dr. Jay Levy (San Francisco). See GraY ET Al., supra note 52, at 310. The intellectual property rights to the discovery precipitated infamous internecine battles between Gallo and Montagnier. See Institut Pasteur v. United States, 10 Cl. Ct. 304 (1986), rev'd, Institut Pasteur v. United States, 814 F.2d 624 (Fed. Cir. 1987).

54. See Donald S. Burke et al., Isolation of HIV-1 from the Blood of Seropositive Adults, J. ACQUIRED. IMMUNE DEFICIENCY SYNDROMES 1159, 1159 (1990). Untested blood products devastated the hemophiliac community, which is dependent on blood transfusions, in the early days of the AIDS epidemic. See SHILTs, supra note 50, at 220-24 et passim. Unfortunately, even with the technology to detect HIV-infected blood readily, "nıore than half of the world's countries fail to perform full tests on 
making epidemiological tracking of the virus possible. ${ }^{55} \mathrm{HIV}$ testing also enabled preventive intervention since individuals could find out whether they were infectious before progressing to full-blown AIDS. ${ }^{36}$ In addition, discovery of the pathways to infection aided preventive efforts because identifying people infected or at risk of infection allowed for targeted intervention, for example, condoms for those at sexual risk, or blood-product testing for those in need of transfusions. ${ }^{57}$

Basic science also profited from isolation of the virus. ${ }^{58}$ Scientists were now able to begin natural history studies of AIDS to begin to understand the way HIV infection progresses to clinical AIDS and eventually to death..$^{59} \mathrm{HIV}$ was identified as a retrovirus, that is, a virus that uses the replicatory machinery of the cells it infects to reproduce itself. ${ }^{60} \mathrm{HIV}$ was also identified as a lentivirus, that is, a virus that engenders acute symptons in the blood upon infection and then remains clinically latent for a long period as it progresses clandestinely throughout the lymphatic system. ${ }^{61}$ These imsights helped scientists devise antiretroviral therapies such as AZT and, later, protease inhibitors, which have shown great promise in slowing progression to AIDS after mitial infection with HIV. ${ }^{62}$

While advances in the understanding and therapeutic treatment of AIDS have been remarkable, several intractable issues have hampered vaccime research. Primary among these have been: (1) variability of the AIDS virus; (2) lack of an appropriate animal model for HIV/AIDS; and (3) uncertainty as to the correlates of protection from the virus. ${ }^{63}$ Since these three obstacles affect trial design and, consequently, the legal and ethical dimensions of vaccine trials, I will discuss each briefly.

donated blood." Geir Moulson, WHO Claims Much Donated Blood Not Tested for HIV: Safest Supplies in Developed Nations, S.F. CHRoN., Apr. 7, 2000, at A2. As a result, it has been estimated that five to ten percent of the people living with HIV were infected via blood transfusions. Id. (citing Yasuhiro Suzuki, director of WHO's health technologies division).

55. See REPORT, supra note 40, at 65-71; Lloyd F. Novick, HIV Seroprevalence Surveys: Impetus for Preventive Activities, 81 AM. J. PUB. Health 61, 61 (1991); David L. Wheeler, Researchers Mark Advances in Tracking AIDS Virus; Prospects for Vaccine Unclear, CHRON. HIGHER ED., June 22, 1988, at A6.

56. See REPORT, supra note 40, at 73-81; Dani P. Bolognesi, Prospects for Prevention of and Early Intervention Against HIV, 261 JAMA 3007, 3007 (1989).

57. See Donald P. Francis et al., Targeting AIDS Prevention and Treatment Toward HIV-IInfected Persons: The Concept of Early Intervention, 262 JAMA 2572, 2572 (1989); GRAY ET AL., supra note 52, at 7; NATIONAL AIDS STRATEGY, supra note 19, at B-31; REPORT, supra note 40, at 8391.

58. See, e.g., Wamer C. Greene, The Molecular Biology of Human Immunodeficiency Virus Type IInfection, 324 New ENG. J. Med. 308 (1991).

59. See Kenneth H. Mayer, The Natural History of HIV Infection and Current Therapeutic Strategies, in AIDS AND THE HealTHCaRe SYSTEM 21, 21-32 (Lawrence O. Gostin ed., 1990).

60. See NIAID, supra note 9 (defining "retrovirus").

61. See Greene, supra note 58, at 308.

62. See discussion supra note 20 and accompanying text.

63. See GRADY, supra note 7, at 93-101; David Baltimore \& Carol Heilman, HIV Vaccines: Prospects and Challenges, 279 Scr. AM. 98, 98-100 (1998). 


\section{B. Variability of the AIDS Virus}

Several different "clades" or genetic sub-types of HIV exist worldwide. ${ }^{64}$ Five to seven principal subgroups of the virus have been identified. ${ }^{65}$ Although these variations are generally divisible geographically, two or more viral clades can exist in a given region. In fact, more than one clade can infect a single individual. ${ }^{66}$ More commonly, variant sub-strains of HIV develop within individuals as the virus mutates irregularly in the body. ${ }^{67}$

One of the most formidable challenges to AIDS vaccine research, then, is to identify a vaccine or vaccines that can protect against all of the extant variations of the virus. ${ }^{68}$ Logistically speaking, of course, this ineans that vaccine trials cannot be conducted solely in one region of the world. ${ }^{69}$ The viral subtype predommant in Thailand, for example, may overcome vaccine-induced immune defenses specific to viral subtypes generally found in the U.S. and Europe. The genetic variation in the AIDS virus, therefore, puts a premium on international cooperation and coordinated research efforts on a global scale. ${ }^{70}$

Cultural and political differences annong the nations can also raise vexing research issues. For instance, western-style informed consent may not "translate" in a country where the infection rate is high and the pressure to devise a viable preventive inechanisin is strong. ${ }^{71}$ Moreover, the inherent danger in an AIDS vaccine trial-that subjects might believe they

64. See Jon Cohen, How Can Viral Variation Be Overcome?, 260 ScIENCE 1260, 1260 (1993); Saladin Osmanov et al., HIV-1 Genetic Variability: Implications for the Development of HIV Vaccines, 48 ANTIBIOTICS \& CHEMOTHERAPY 30, $30-38$ (1996).

65. See GraDY, supra note 7, at 99.

66. See Jon Cohen, Can One Type of HIV Protect Against Another Type?,268 SCIENCE 1566, 1566 (1995); J. Travis, HIV-2 Offers Protection Against HIV-1, 147 ScI. NEws 373, 373 (1995).

67. See NIAID, Challenges in Designing HIV Vaccines 3 (1997).

68. See id.

69. In vitro assays might seem to be a logical alternative, but $\mathrm{HIV}$ antibodies in a test-tube (laboratory isolates) behave differently than HIV "out there" in the world (field isolates). "What is needed is a vaccine capable of inhibiting a spectrum of field isolates, not just laboratory strains of virus." GRADY, supra note 7, at 100.

70. See discussion supra notes 27-29 and accompanying text. The ethical and legal issues presented by international drug trials are very complex and, as such, they lie beyond the scope of this Comment. Except for brief allusions, the focus liere is restricted to domestic AIDS vaccine trials. For more extensive treatment of the ethical issues at stake im mternational trials, see UNAIDS, ETHICAL Considerations in HIV Preventive Vaccine Research (2000). On some of the legal issues presented, see John P. Wilson, Limitation of Manufacturer Liability for Administration of an AIDS Vaccine Overseas, 30 INT'L LAW. 783 (1986).

71. Jeremy Sugarman has identified meaningful informed consent as a "particularly salient problem" in Phase III clinial trials of HIV-preventive vaccines. Jeremy Sugarman, Towards Achieving Meaningful Informed Consent in AIDS Vaccine Trials with Injection Drug Users, 9 AIDS \& PuB. PoL'Y J. 167, 167 (1994). For a good introduction to some of the problems raised by informed consent in other countries, see Olandim Queiroz da Fonseca, Jr. \& Reidar K. Lie, Informed Consent to AIDSVaccine Trials in Brazil: A Pilot Study, 10 AIDs \& PUB. POL'y J. 22 (1995). I make some rudimentary suggestions as to how informed consent in domestic efficacy trials might be improved infra Part V.C.2. 
are protected and engage in heightened risk behavior as a result ${ }^{72}$-may prove to be particularly acute in cultures unfamiliar with Western forms of medicine. Finally, stigmatized groups, such as homosexuals in many countries, may encounter severe forms of persecution associated with trial participation. In sum, the genetic variation in the AIDS virus necessitates trial design on an international scale with all of the attendant cultural challenges.

\section{The Lack of an Appropriate Animal Model for HIV/AIDS}

Clinical research involving experimental substances is usually preceded by testing in animals. ${ }^{73}$ Generally speaking, before a candidate vaccine is approved for testing in humans, it must be deinonstrated to be safe, ${ }^{74}$ immunogenic, ${ }^{75}$ and effective ${ }^{76}$ in animals. Scientists usually evaluate a new vaccime by testing its ability to generate antibodies in animals. They then test the effectiveness of these antibodies in neutralizing the virus through im vitro laboratory tests. With soine diseases, however, animal infection does not closely mimic the characteristics of infection and immune response in humans. ${ }^{77}$ In such cases, the analogy between animal disease and human disease breaks down, making it difficult to draw reliable inferences froun the animal data. Initial testing, therefore, is often a "guessing game until the human model is used."78

To date, no suitable animal models for HIV and no reliable in vitro markers for efficacy have been identified. ${ }^{79}$ The closest candidate is Simian Immunodeficiency Virus (SIV). SIV infects several subspecies of monkey, and macaques have shown varying degrees of protection against SIV challenge after vaccination with a variety of SIV vaccines. ${ }^{80}$ In the final

72. See discnssion supra notes 24-26 and accompanying text.

73. See generally N. Nathanson, Towards an AIDS Vaccine: The Role of Primate Models, 9 INT'L J. STDs \& AIDS 3 (1998).

74. "[T] $]$ he vaccine ... must produce protective immunity with only minimal side effects (such as redness and soreness at the vaccination site) for the overwhelming majority of those who receive it." NLAID, supra note 1 , at 4.

75. "The vaccine ... must cause a strong and measurable immune response." Id. at 6.

76. The vaccine must "produce a desired clinical effect, such as protection against a specific disease, at the optimal dosage and schedule in a given population." Id. at 30 .

77. See GrADY, supra note 7, at 25.

78. Id.

79. Id. at 96.

80. See, e.g., N. Almond et al., Protection by Attenuated Simian Immunodeficiency Virus in Macaques Against Challenge with Virus-Infected Cells, 345 LANCET 1342 (1995); Christopher Joyce, Monkey Tests Raise Hopes of AIDS Vaccine, 124 New ScIENTIST 18 (1989); Michael Murphey-Corb et al., A Formalin-Inactivated Whole SIV Vaccine Confers Protection in Macaques, 246 SCIENCE 1293 (1989). Scientists have also learned from cat research. See, e.g., Oswald Jarrett, The Relevance of Feline Retroviruses to the Development of Vaccines Against HIV, 12 AIDS RES. \& HuM. RETROVIRUSES 385 (1996). 
analysis, though, "SIV is a surrogate for HIV, and it is not known whether successful SIV strategies can be translated to HIV."

Chimpanzees are the only animals that researchers have successfully infected with HIV. ${ }^{82}$ Although they exhibit HIV-like symptoms upon infection, chimps do not develop T-cell deficiencies or other disease symptoms similar to AIDS in humans. ${ }^{83}$ Chimps are a relatively rare species requiring extremely expensive care, which further inhibits experimentation. ${ }^{84}$ If researchers could pinpoimt why chimpanzees do not progress to disease, it might be a significant advance in the treatment of AIDS. Currently, though, chimpanzees represent an expensive and imcomplete analogue for human vaccime research. ${ }^{85}$

The lack of an appropriate animal model raises a thorny question in much of the HIV/AIDS research to date: Should researchers be testing experimental substances in humans before they are known to be safe, immunogenic, and protective in animals ${ }^{26}$ Since a preventive vaccine must, by definition, be tested in HIV-negative human subjects, the stakes are quite high: AIDS is currently a fatal disease with no known cure. Without reliable animal data, researchers take the risk that some individuals will expose themselves to HIV based on maccurate assunuptions about vaccime

81. GRADX, supra note 7, at 97.

82. See, e.g., Philip Cohen, Chimps Beat HIV with Loop Vaccine, 154 NEw ScIENTIST 16 (1997); Kathleen Fackelmann, Vaccine Shields Chimps from HIV, 151 Sci. NEws 309 (1997); Patricia N. Fultz et al., Vaccine Protection of Chimpanzees Against Challenge with HIV-1-Infected Peripheral Blood Mononuclear Cells, 256 SCIENCE 1687 (1992); Michael D. Lubeck et al., Long-Term Protection of Chimpanzees Against High-Dose HIV-1 Challenge Induced by Immunization, 3 NATURE MED. 651 (1997); K.E. Ugen, Nucleic Acid Immunization of Chimpanzees as a Prophylactic/Immontherapeutic Vaccination Model for HIV-I: Prelude to a Clinical Trial, 15 VAcciNe 927 (1997).

83. See GRADY, supra note 7, at 97.

84. At approximately $\$ 70,000$ per chimp, animal tests exact a prohibitive toll for many research efforts. See id. at 99 . Grady further notes that animal research has been limited by "sociopolitical concerns about the use of animals in research." Id. at 25.

85. This is not to say that primate research represents a dead-end in the search for an AIDS vaccine. As NIAID has recognized,

important information has been obtained from both monkeys and chimpanzees. Experiments in both species have demonstrated the feasibility of developing a protective vaccine. Moreover, a new animal model-infection of macaques with a chimeric virus (SHIV) based on SIV but including the HIV envelope, with subsequent developinent of disease-may become extremely valuable for evaluating candidate $H I V$ vaccines.

NIAID, supra note 67 , at 6 .

86. As Hans Jonas presciently argued, the transition from animal research to human research always involves a risk of this sort: "Up to a point, animals may fulfill the proxy role of the classical physical experiment. But in the end man himself must furnish knowledge about himself, and the coinfortable separation of noncommital experiment and definitive action vanishes." Hans Jonas, Philosophical Reflections on Experimenting with Human Subjects, in LAW, SCIENCE AND MEDICINE 987, 988 (Judith Areen et al. eds., 1996). The structural necessity to cross the threshold from animal to human experimentation, however, does not mean that ethical categories are thereby voided. On the contrary, Jonas asserts that "[h]uman experimentation for whatever purpose is always also a responsible, nonexperimental, defimitive dealing with the subject himself. And not even the noblest purpose abrogates the obhigations this involves." Id. 
efficacy. On the other hand, the epidemic is spreading at such an advanced rate that a genuinely effective vaccine could save millions of lives. The societal benefits from vaccine research arguably outweigh the individual risks voluntarily assuined by trial participants. ${ }^{87}$ Such a risk/benefit analysis now supplies an ex post rationalization for the AIDS vaccime effort. As Grady notes: "Because of the urgency of the public health need and public attention and political pressure, human Phase I trials of HIV candidate vaccines began before efficacy was demonstrated in chimpanzees or any other animal model." $" 88$

\section{Uncertainty as to the Correlates of Protection}

Once testing begins in humans, researchers face another important question: How will they know if a candidate vaccine has actually resulted in some level of protection to an individual? Researchers do not currently know what a protected individual looks like because humans naturally immune to HIV infection have not been identified. ${ }^{89}$ To know whether a vaccine is protective, in other words, researchers must first identify the correlates of protection against HIV infection. ${ }^{90}$

With many diseases, the presence of antibodies in the blood functions as a sign that the individual has either been infected with and overcome the disease or, $\mathrm{m}$ the alternative, has been successfully inoculated. ${ }^{91}$ This is not the case with HIV. HIV-infected persons register high levels of antibodies, including antibodies capable of neutralizing the virus in vitro, but they are still not protected against disease progression. ${ }^{22}$ Although antibody presence does not inhibit progression to AIDS, however, this does not mean that antibodies afford no protection against HIV infection: "Most of the vaccine experiments performed to date are banking on this hypothesis."93

Grady's choice of words-"banking on"-is curiously apt. At this point, there is no way to know whether HIV antibodies afford any

87. The problem recapitulates, in many senses, the dilemma for people infectcd with HIV who are interested in trying experimental therapies. See generally Lois K. Perrin, Note, The Catch-22 for Persons with AIDS: To Have or Not to Have Easy Access to Experimental Therapies and Early Approval for New Drugs, 69 S. CAL. L. Rev. 105 (1995) (discussing the tension between personal autonomy and public health in the access to experimental treatments).

88. GRADY, supra note 7, at 99 .

89. Researchers have been carefully examining people identified as "slow progressors," that is, those who are infected with HIV and do not seem to advance to clinical disease or AIDS. See, e.g., Susan P. Buchbinder et al., Long-Term HIV-I Infection Without Immunologic Progression, 8 AIDS 1123 (1994); Jon Cohen, New Clues Found to How Some People Live with HIV, 270 Science 917 (1995); Kathleen Fackelmann, Staying Alive: Scientists Study People Who Outwit the AIDS Virus, 147 SCI. NEws 172 (1995).

90. See Jon Cohen, What Are the Correlates of Protection?, 260 ScIENCE 1259, 1259 (1993).

91. See Anthony S. Fauci, Optimal Immunity to HIV-Natural Infection, Vaccination, or Both?, 324 NEw Eng. J. MED. 1733, 1733 (1991).

92. See GRADY, supra note 7, at 93 .

93. Id. at 94 . 
protection against HIV infection. AIDS vaccine trials are designed, in part, to identify the correlates of protection contemporaneously with the generation of protection. In plain terms, the only way to know if an AIDS vaccine is working is to test it in HIV-negative people who are likely to be exposed to the virus; researchers cannot ethically "challenge" subjects directly with a deadly virus to test vaccine efficacy. If high-risk individuals $\mathrm{m}$ the vaccine arm of a research study demonstrate a statistically significant difference in infection rates from similarly at-risk individuals in the placebo or control arm, then it is logical to assume that the vaccine has afforded some degree of protection. ${ }^{94}$ Researchers can then work backwards, in a sense, to identify the correlates of protection based on the empirical verification of efficacy.

To summarize, trial design in AIDS vaccine research is anomalous in at least three ways: (1) viral variation makes the target both inultiple and self-modifying; (2) research has been initiated in huinans before efficacy has been demonstrated in animals; and (3) the correlates of protection will theoretically emerge, ex post facto, from the comparative infection rates of high-risk individuals mjected with vaccime versus those mjected with placebo. Part III explores how these necessary anomalies in trial design affect the often vulnerable imdividuals and communities from which research subjects must be drawn in domestic AIDS vaccine research. In other words, Part III moves from the scientific challenges to the intimately related sociopolitical and legal challenges facing the domestic AIDS vaccime effort.

III

\section{Social HaRm AND AIDS Vaccine RESEARCH}

In 1994, the AIDS Vaccine Evaluation Group (AVEG) ${ }^{95}$ conducted a confidential survey of 247 participants at high risk of HIV infection in

94. See Collins, supra note 7 , at 7 . Obviously it will take a large number of participants to power such a study. A statistically significant disparity can be generalized only if it occurs regularly across a significant population. "HIV-vaccine research and development differs from the development of treatments in that testing of efficacy cannot be targeted at specific individuals but must be done in large-scale trials to assess the effectiveness of the vaccine against a 'natural' rate of infection." ENCYCLOPEDIA OF AIDS, supra note 42, at 435.

95. The AVEG is a multi-centered organization established by the NIAID Division of AIDS (DAIDS) as part of its program to develop AIDS vaccines. See MichaEl LaNGaN \& Chris Collins, Paving the Road to an hiv Vaccine: Employing Tools of Public Policy to Overcome Scientific, Economic, Social and Ethical Obstacles 5-8 (Center for AIDS Prevention Studies, Univ. of Cal. San Francisco, Monograph Series, 1998) (providing a helpful overview of the U.S. government's involvement in AIDS vaccine research). "The AVEG has historically focused on early safety and immunogemicity trials, and correlative laboratory studies of candidate preventive vaccimes." Id. at 7. DAIDS has also established the HIV Network for Prevention Trials (HIVNET), which "has a broader agenda that includes trials of vaccines, topical microbicides, STD treatment, behavioral interventions, and approaches to prevent mother-to-infant transmission. [HIVNET] has focused primarily on efficacy trials in an international multi-center network." Id. NIAID is currently 
Phase II trials of gp120.96 The survey was designed to support a systematic assessment of the social risk of HIV vaccine trial participation. ${ }^{97} \mathrm{~A}$ full eighteen percent of those surveyed reported trial-related adverse social events. ${ }^{98}$ Many of these adverse events were admittedly de minimis or beyond the scope of legal imtervention (for example, "I told a friend I might test ELISA-positive on a test and he started being careful about sharing food with me."99). Others, however, give serious reason for pause: A "volunteer reported that he tested positive during a hospitalization, and that the imsurance company was notified and in turn notified the employer, who fired the volunteer. This volunteer reported losing health insurance when the job was lost." 100

This nameless, faceless "volunteer"101 stands as an emblem of the social risks faced by participants in AIDS vaccine trials. The participant lost his job and his health insurance, but it is not altogether clear how this happened. Did the disclosure of his apparent HIV-positive serostatus (hospital to insurance company to employer) take place without his knowledge and without a chance to explain the test result? Or did the volunteer try to explaim the result, with the insurance company, the employer, or both drawimg inferences from his participation in the trial ? $^{102}$ Either way, this brief and anonymous anecdote serves as a cautionary tale to trial participants and researchers alike.

The followimg subsections examine two possible bases for trial-related discrimination: An antibody-positive HIV test, and disclosure of AIDS vaccine trial participation. ${ }^{103}$ Although the focus will be on potential harm

consolidating and redistributing its vaccine research programs to develop an HIV Vaccine Trials Network (HVTN) and HIV Prevention Trials Network (HPTN). See AVAC, supra note 27, at 32-33. On NIAID's involveinent in ADS vaccine research generally, see NIAID, Clinical Research on AIDS Vaccines (visited Apr. 3, 2000) <http://www.niaid.nih.gov/factsheets/clinrsch.htm>.

96. See Sheon et al., supra note 7, at 520 .

97. See id. at 523 .

98. See id. at 524 .

99. Id. at 522 .

100. Id.

101. The use of the term "volunteer" to describe this participant begs the question: Was his participation truly voluntary? Did he know what he might get into? Hans Jonas's broad concept of voluntariness in human subject experimentation rings oddly in this context: "Only genuine authenticity of voluuteering can possibly redeein the condition of thinghood to whieh the subjeet submits." Jonas, supra note 86 , at 989 . Jonas distinguishes geuuine volunteering froin consent narrowly defined: "Mere "consent' (Inostly amounting to no more than permission) does not right this reification." Id.

102. A third possibility is that the participant actually seroconverted. Due to an error in the design of the trial, however, "it was not possible to determine whether the rcportcd positive tcst results werc due to actual infections from high risk behavior or froin vaccine-induced antibody reaetions." Sheon et al., supra note 7 , at 522 .

103. It is worth einphasizing that discrimination against people who test positive for HIV, whether they actually lrave the virus or have only generated antibodies, derives from discriminatory attitudes towards HIV-positive people generally. In other words, the need to protect participants in AIDS vaccine trials (who are HIV-negative) derives, in large ineasure, froin the stiginatization of HIVpositive people as such. Aside from its general desirability, then, reducing the stigina associated with 
to participants, this harm can also impede AIDS vaccine research as a whole. If social harms in early trials are not managed effectively, publicized harms may dry up voluntary enrollment. Potential discrimination, then, will be analyzed both as an issue of individual harm to research subjects and as a more general threat to the vaccine effort.

\section{A. Discrimination Based on Vaccine-Induced Seropositivity}

The HIV Network for Prevention Trials (HIVNET) ${ }^{104}$ recently conducted a Vaccime Preparedness Study among HIV-negative homosexual men, male and female mjection-drug users, and non-injecting women at heterosexual risk. ${ }^{105}$ Participants ranked false-positive HIV tests as their number one concern in the realm of social risks: ${ }^{105}$

A major concern across all study populations was vaccine-imduced seropositivity. Study sites will need to emphasize to participants that testing to discriminate actual HIV-1 infection from vaccine-imduced seropositivity will be available at the study site, as needed. However, participants need to understand that if they test outside of the study site, HIV-1 antibody-positive results found by conventional serologic tests may not be able to distinguish infection from vaccine-induced seropositivity, and these results may lead to possible discrimination or other social harms. ${ }^{107}$

As this quotation suggests, researchers expect some version of informed consent ${ }^{108}$ to minimize potential harm based on false seropositivity ("Study sites will need to emphasize" and "participants need to understand" being the operative phrases). They also emphasize that specialized tests available at the study site will ensure that vaccine-mduced antibody response will be distinguishable from actual seroconversion. ${ }^{109}$ Ultimately, the goal is to

HIV protects human subjects from potential social harm and enhances the likelihood that a successful AIDS vaccine will be produced for all.

104. On HIVNET, see discussion supra note 95.

105. See Koblin et al., supra note 7, at 786.

106. See id. at 788-90.

107. Id. at $791-92$.

108. Federal regulations promulgated by the Department of Health and Human Services (HHS) require researchers to disclose "any reasonably foreseeable risks or discomforts to the subject." 45 CFR $\S 46.116(\mathrm{a})(2)$ (1998). Full disclosure, however, may not always be in the interest of researchers: "There are, of course, countervailing pressures that work against complete honesty. For instance, if all possible harmful effects were discussed in detail, it is possible that few people would be willing to participate." GRAY ET AL., supra note 52, at 42. For further discussion of informed consent in AIDS vaccine trials, see infra Part V.C.2.

109. VaxGen has issued a letter to partieipants assuring them that they will have access to tests that distinguish HIV infection from seroconversion due to vaccination. See Letter from Donald $P$. Francis, President of VaxGen, Inc. to volunteers (on file with author) [hereinafter VaxGen Letter]. While access to such a test may help to explain why a participant has tested positive for antibodies on a standard blood test, it does nothing to prevent misdiaguosis and ensuing discrimination in the first place. Nor are insurers or others who rely on blood testing data obliged to consult VaxGen. While antibodies to the AIDSVAX gp120 product are relatively easy to distinguish from HIV antibodies 
shield participants from harm by limiting disclosure of their blood-test results. Given the prevalence of blood testing in our society, though, it is unlikely that participants will be able to confine testing to the research site, even if they might otherwise choose to do so. "In most states, insurance carriers are permitted to require HIV testing of insurance applicants, and the U.S. federal government requires HIV testing for military recruits, foreign service officers, Job Corps participants, prison inmates, and persons applying to immigrate or becoine naturalized citizens." 110 During a participant's lifetime, it is highly improbable that every blood test can take place at the study site. Many, if not all, potential study participants will therefore have to face squarely the possibility of discrimination based on a falsepositive blood test. ${ }^{111}$

Why should we assume that einployers, prison officials, immigration officers, and other similarly situated decision inakers might discriminate against people who seein to be HIV-infected? Unfortunately, attitudes towards people living with HIV/AIDS have not progressed as quickly as medical treatinent of the disease:

About half of American adults say that they would avoid a grocery store if the owner had AIDS, and nearly one-third advocate the quarantine and publication of the names of people with the disease. Almost half continue to believe that soine forms of casual contagion (e.g., a kiss on the cheek) or airborne transmission (e.g., sneezing) can result in HIV infection. ${ }^{112}$

using specialized assays, moreover, "[m]ore complex vaccines that may be tested in the future could be more likely to react with commercially available tests." Sheon, supra note 7, at 524. Among the priorities established for the National Institutes of Health by President Clinton's National AIDS Strategy Taskforce is production of more sensitive blood assays to distinguish vaccine antibodies from natural infection. See NATIONAL AIDS STRATEgY, supra note 19, at B-29. See generally David H. Schwartz et al., Extensive Evaluation of a Seronegative Participant in an HIV-1 Vaccine Trial as a Result of False-Positive PCR, 350 LANCET 256 (1997) (concluding that the desigu of efficacy trials for new vaccines should be in parallel with the development of diagnostic tests capable of distinguishing vaccine-induced antibodies from true HIV infection); Jonathan Weber, Distinguishing Between Response to HIV Vaccine and Response to HIV, 350 LANCET 230 (1997) (predicting that newer vaccines will produce antibody responses which will be practically indistinguishable from true infection using standard ELISA/Western Blot assays).

110. Sheon et al., supra note 7 , at 523 .

111. VaxGen is offering participants a study ID card to document participation in the AIDSVAX trial. See VaxGen Letter, supra note 109. The use of study ID cards, however, has backfired in some instances in Phase II trials of gp120:

Inadvertent disclosure of trial participation was very distressing in a small number of cases. Identity cards confirming the volunteers' participation were used deliberately by only 3 volunteers but were used against 2 others. Prospective volunteers should thus be asked to weigh the risks of someone's fimding the card against the potential benefits that the card could offer in the event of a false-positive HIV test result.

Sheon, supra note 7, at 524. By carrying a study ID card, in other words, participants may inadvertently jump from the "false seropositive" frymg pan into the "trial participant = high risk individual" fire discussed in Part III.B infra.

112. GRAY ET AL., supra note 52, at 164 (references omitted). 
With paranoia about contagiousness still rampant, it is no wonder that Americans treat people living with HIV/AIDS as social lepers.

Judge Broderick of the U.S. District Court for the Eastern District of Pennsylvania, under the palpable influence of Susan Sontag's AIDS and its Metaphors, ${ }^{113}$ has written eloquently about American society's attitudes towards perceived "HIV carriers":

[S]ince first identified in the early 1980 s as a distinct inedical condition, AIDS has engendered such prejudice and apprehension that its diagnosis typically signifies a social death as concrete as the physical one which follows .... The particular associations AIDS shares with sexual fault, drug use, social disorder, and with racial minorities, the poor, and other historically disenfranchised groups accentuates the tendency to visit condemnation upon its victims. AIDS mythology has fomented not only private judgments about carriers of the virus. It has spawned calls for punitive, oppressive official action against them .... Vast segments of the American populace favor the forced quarantine of persons with AIDS, tattooing HIV-positive persons for ready identification, and banishing HIV carriers from the workplace and school. Thus, to conclude that persons with AIDS are stigmatized is an understateinent; they are widely stereotyped as indelibly miasmic, untouchable, physically and morally polluted..$^{114}$

If Judge Broderick's rhetoric seems somewhat melodramatic a decade later, consider the remarks of some our country's most powerful legislators opposing the Americans with Disabilities Act of 1990. The ubiquitous Senator Jesse Helms of North Carolina opined: "I do not understand why ... you went down the road of mcluding in your definitions people who are HIV-positive, because 85 percent or more of the HIV positive people in this country are known to be drug users or homosexual or both." 115 Not to be outdone, Representative Dan Burton of Indiana tersely stated: "The ADA is the last ditch atteinpt of the remorseless sodomy lobby to achieve its national agenda before the impending decimation of AIDS destroys its political clout." 116 Heated rhetoric aside, the point need not be belabored ad nauseam: Discrimination agamst people perceived to have HIV or AIDS is an American reality.

113. SUSAN SONTAG, AIDS AND 1TS METAPHORS (1989).

114. Cain v. Hyatt, 734 F. Supp. 671, 679-80 (E.D. Pa. 1990) (citations omitted) (awarding plaintiff, an aggrieved attorney, $\$ 157,888.18$, including $\$ 50,000$ in punitive damages, in a case of AIDS discrimination brought under state law).

115. 135 CONG. REC. S10768 (1989) (statement of Sen. Helms).

116. 135 CoNG. REc. H22734 (1989) (statement of Rep. Burton). The legislative history of the ADA, with special attention to homosexuality and HIV, is nicely summarized in John Douglas, Comment, HIV Disease and Disparate Impact under the Americans with Disabilities Act: A Federal Prohibition of Discrimination on the Basis of Sexual Orientation?, 16 BERKELEY J. EMP. \& LAB. L. 288, 307-13 (1995). 


\section{B. Discrimination Based on Trial Participation as an Indicator of Risk-Group Status}

As the remarks of Senator Helms and Representative Burton attest, the association between AIDS and homosexuality or drug use is commonplace. The association works in both directions: Injection drug users and homosexuals are often presumed to be HIV-positive, and those who are HIV-positive are often presumed to be homosexuals or injection drug users.

Given this reflexive association, the effort to enroll participants in an AIDS vaccine trial can be tricky business. On the one hand, researchers will need to reach out to affected commumities to assemble trial cohorts that can tell them something about a candidate vaccine's efficacy. As discussed earlier, researchers will need to test vaccines in HIV-negative subjects at high risk of infection. ${ }^{117}$ On the other hand, by reaching out to those who take part in high-risk behaviors, researchers will be relying upon and reinforcing some of the very associations that stigmatize affected populations. ${ }^{118}$ Future efficacy trials will have to assemble in the neighborhood of 5000 participants for each Phase III trial. Each time a flyer, billboard, newspaper, radio, television, or Internet advertisement publicizes the riskgroups needed for AIDS vaccine trials for recruitment purposes, it also informs those who would discriminate that participation correlates with highrisk behavior.

\section{Trial-Related Discrimination as a Disincentive to Participate}

The two forms of discrimination discussed above-discrimination based on vaccine seropositivity or on trial participation itself-could have adverse consequences for the AIDS vaccine effort. First, individual participants may suffer the consequences of trial-related discrimination. HIVnegative research volunteers, many of whom decide to participate based on altruism, would be exposed to social harms. Since these volunteers place

117. See supra Part II.D.

118. The HIVNET Vaccine Preparedness Study, for example, recruited "HIV-1 negative homosexual men, male and female injecting drug users and non-injecting women at heterosexual risk," Koblin et al., supra note 7, at 785, clinical-speak for gays, addicts, and prostitutes. Sheon and her colleagues made a good-faith, if half-hearted, stab at addressing this problem: "[I]t seems prudent to consider including both high-risk and low-risk voluntecrs in future efficacy trials. If trial sponsors widely publicize the fact that trials include both high-risk and low-risk volunteers, stignatization of volunteers may be reduced." Sheon et al., supra note 7 , at 525 . Such a remedial ineasure is questionable on at least three grounds. First, it entirely neglects the distorting effects enrolling low-risk individuals would have on trial data. Second, it also neglects the considerable expense involved in screening, consenting, enrolling, and processing individuals who would contribute nothing to the actual findings of the experiment. Third, it naively assumes that private sponsors will expend their resources on media counter-spim campaigns that have, at best, little chance of reducing stigina. As suggested infra Part V, legislative and regulatory measures ained at protecting participants offer a more robust alternative. 
theinselves in a vulnerable position in the interest of public health, it is imperative as a matter of individual justice that we protect them. ${ }^{119} \mathrm{~A}$ second consideration is potential harm to the vaccine effort itself. If trial participants are exposed to unnecessary harm and their experience is communicated to their constituent communities, the lngh-risk volunteers so essential to the success of efficacy trials might quickly become averse to participation. ${ }^{120}$ As Mark Harrington has observed, "vaccine trials will be subjected to unprecedented worldwide scrutiny."121 One adverse event, with enough publicity, could radically impede recruitment efforts and trials generally.

Although researchers recognized the potential for social harms long ago, the remedial measures they have devised are, at best, weak. Providing for HIV testing at the study site is helpful, as far as it goes, but participants will often be required to undergo HIV tests off-site. Vaccine-induced seropositive results are bound to occur, especially as vaccines advance and antibody responses grow increasingly difficult to distinguish from natural infection. Specialized assays to distinguish HIV antibodies from vaccineinduced antibodies will be a welcome innovation, but they inust be widely produced, dissemmated, and employed to help in any meaningful way. In addition, specialized assays may become a logistical nightmare as several different vaccine candidates reach Phase III trials and therefore turn up more frequently in the blood of the general population. Study ID cards and phone calls from researchers assuring individuals that trial participation is the source of false-positive HIV tests also provide little solace. Simce study participation stands as a virtual proxy for risky behavior such as sodomy, drug use, and promiscuity, disclosure of trial participation simply replaces one potential basis of discrimination with another. Finally, traditional informed consent procedures do not appear to square well with the unique elements of the AIDS vaccine effort. It is hardly possible to anticipate all

119. As Gary Ellis, director of the Office for Protection from Research Risks (OPPR), has stated: "Respecting the rights of research subjects and providing for their welfare is to honor a deep obligation to those individuals who make a remarkable contribution to the common good by volunteering to serve as research subjects." Gary Ellis, Keeping Research Subjects Out of Harm's Way, 282 JAMA 1963, 1964 (1999).

120. In African American communities, for instance, suspicion of medical experimentation runs deep ever since word of the shockingly exploitative Tuskegee syphilis experiments became public. Although unquestionably justified by the historical record, such suspicion can also do considerable damage. Now that effective treatments for AIDS exist, for instance, it is becoming increasingly clear that African Americans are not benefiting from antiretrovirals as inuch as whites. See JAMEs H. JONES, BAD Blood: The Tuskegee Syphilis Experiment 220-42 (2d ed. 1993). For other trenchant discussions of the shadow Tuskegee casts over AIDS research, see Allan M. Brandt, Racism and Research: The Case of the Tuskegee Syphilis Study, 8 Hastings CTR. REP. 21 (1978); David L. Kirp, Blood, Sweat, and Tears: The Tuskegee Experiment and the Era of AIDS, 10 TIKKUN 50 (1995); Deborah L. Shelton, Legacy of Tuskegee, AM. MED. NEws, June 3, 1996, at 11.

121. Mark Harrington, Constitutency Priorities in AIDS Vaccine Research: One Perspective, 8 AIDS Res. \& HUM. RETROVIRUSES 1431, 1431 (1992). 
potential "risks or discomforts"122 that may arise socially as a result of trial participation or false-positive HIV tests. An attempt to catalogue exhaustively the potential social risks might simply produce debilitating anxiety in the vulnerable participants essential to AIDS vaccine research.

In conclusion, the potential for social harms, when combined with the physical risks of vaccime research, may prove an overwhelming disincentive to participate in AIDS vaccine trials. Given the weak remedies that researchers have proposed thus far, participants in efficacy trials may well be exposed to considerable social harm. If participants are harmed, this will be probleinatic both as a matter of mdividual justice and as a potential threat to recruitment for future trials. Simce it is likely that several Phase III trials will be necessary to identify an effective product, and since the need for an effective AIDS vaccime is so acute, more robust ways must be found to protect trial participants. Part IV therefore turns to federal disability discrimination law to examine one viable, but ultimately uncertain, avenue of protection.

\section{IV}

\section{DoEs the ADA PRotect AIDS VACCINE RECIPIENTS?}

Anticipating trial-related social harms, researchers naturally turned to extant legal protections to see if the fears of participants might be reasonably allayed. One potential source of protection seized upon early by legal analysts was the Americans with Disabilities Act of $1990 .{ }^{123}$ The following Part evaluates whether the ADA offers the kind of protection against trial-related discrimination that AIDS vaccine researchers and their legal advisors have envisioned. In light of recent Supreme Court decisions construmg the Act, this Part concludes that ADA protection is, at best, unreliable in this context.

\section{A. HIV/AIDS and the Americans with Disabilities Act of 1990}

The ADA was pronulgated "to address the major areas of discrimination faced day-to-day by people with disabilities." 124 Title I of the Act applies to discrimination in employment, ${ }^{125}$ Title II to public services, ${ }^{126}$

122. 45 C.F.R. $\S 46.116$ (a)(2) (1998) (providing that a description of foreseeable risks and discomforts involved in participation be given to participants as part of the informed consent process). For suggestions as to how informed consent might be tailored to AIDS vaccine trials, see discussion infra Part V.C.2.

123. See discussion infra Part V.A.

124. 42 U.S.C. $\$ 12101$ (b)(4) (1994). The Act mentions "discrimination against individuals with disabilities ... in such critical areas as employment, housing, public accommodations, education, transportation, communication, recreation, institutionalization, health services, voting, and access to public services" in legislative findings. Id. $\$ 12101(\mathrm{a})(3)$.

125. See id. §§ 12111-12117.

126. See id. §§ 12131-12165. 
and Title III to public accommodations and services operated by private entities. ${ }^{127}$ The Act covers private employers with fifteen or more employees $^{128}$ as well as state and local governments. ${ }^{129}$ The ADA was not the first federal legislation to address discrimination against disabled people. Congress had earlier passed the Rehabilitation Act of 1973, ${ }^{130}$ which applies to federal agencies ${ }^{131}$ and private entities receiving federal assistance. ${ }^{132}$

The ADA sets forth a three-pronged definition of disability. It defimes "disability" with respect to an individual as:

(A) a physical or mental impairment that substantially limits one or more of the major life activities of such individual [the "actual disability" prong]; (B) a record of such an impairment [the "record of" prong]; (C) being regarded as having such an impairment [the "regarded as" prong].

Individuals who fit into any of these three prongs of the definition of disability are protected from discrimination if they are "otherwise qualified." "I34 In the employment context, individuals are otherwise qualified if they can perform the essential functions of the position with or without reasonable accommodation. ${ }^{135}$ Individuals are not otherwise qualified if they pose a direct threat to the health or safety of others. ${ }^{136}$

The question that might arise in future ADA litigation involving AIDS vaccme recipients can be concisely stated: Does an imdividual who

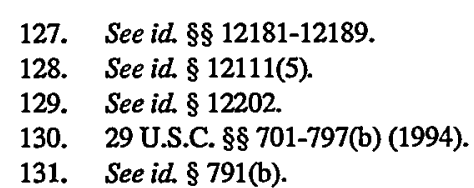

132. See id. §§ 793-794. The ADA expressly incorporates Rehabilitation Act standards as a "floor" for purposes of the Act. See 42 U.S.C. § 12201(a)(1994). In addition, Congress directed that enforcement agencies develop procedures to ensure that administrative complaints filed under the ADA and under the Rehabilitation Act are dealt with in a manner that "avoids duplication of effort and prevents imposition of imconsistent or conflicting standards." Id. $\$ 12117(\mathrm{~b})$. The Equal Employment Opportunity Commission (EEOC), responsible for enforcenent of Title I of the ADA, inade Rehabilitation Act regulations and case law a cornerstone of its regulatory drafting for the ADA:

The format of part 1630 reflects congressional intent, as expressed in the legislative history, that the regulations implementing the employinent provisions of the ADA be modeled on the regulations implementing section 504 of the Rehabilitation Act of 1973, as amended, 34 CFR part 104. Accordingly, in developing part 1630, the Commission has been guided by the section 504 regulations and the case law interpreting those regulations.

56 Fed. Reg. 35,726 (1991). Since Rehabilitation Act regulations and precedent have been widely held to apply in ADA cases, the following discussion assunes this without further analysis.

133. 42 U.S.C. \& $12102(2)$ (1994).

134. Id. $\S 12111(8)$.

135. The term "reasonable accommodation" (defined at $i d . \S 12111(9)$ ) has been the source of extensive litigation. See generally Mary L. Topliff, Remedies Available under Americans with Disabilities Act (42 U.S.C.A. $\$ 12101$ et seq.), 136 A.L.R. FED. 63 (1997). Because reasonable accommodation is not, as a general nnatter, reqnired by people who test false-positive for HIV, this issue vill not be treated further.

136. See 42 U.S.C. \& 12113(b). 
tests false-positive for HIV potentially qualify for protection as "disabled" under the Act? The first prong of the Act's disability definition clearly seems mapposite: A false-positive HIV test probably does not constitute "a physical or mental impairment." 137 The second and third prongs, however, may plausibly be construed to cover the scenario. A false-positive HIV test arguably constitutes a "record of" impairment. Moreover, a complainant alleging discrimination based on a false-positive result could logically claim she was "regarded as" impaired by an employer or other relevant decision maker.

Before turning to the relevant case law, it is helpful to explain why the ADA protects individuals as "disabled" who do not actually suffer any mental or physical impairment in the traditional sense. In other words, what is the rationale behind the "record of" and "regarded as" prongs of the ADA's defimition of disability? Why should an entirely healthy individual, such as an AIDS vaccine recipient who suffers no actual physical harm from the vaccine but who tests HIV-positive nevertheless, qualify as "disabled"? Justice Brennan eloquently stated the rationale behind the protection of perceived disabilities in School Board of Nassau County $v$. Arline: ${ }^{138}$

[S]ociety's accumulated myths and fears about disability and disease are as handicapping as are the physical limitations that flow from actual impairment. Few aspects of a handicap give rise to the saine level of public fear and misapprehension as contagiousness. Even those who suffer or have recovered from such noninfectious diseases as epilepsy or cancer have faced discrimination based on the irrational fear that they might be contagious. The [Rehabilitation] Act is carefully structured to replace such reflexive

137. The EEOC and Department of Justice (DOJ) regulations attempt to capture the full range of impairments that qualify uuder the Act:

Physical or mental impairment means:

(1) Any physiological disorder, or condition, cosmetic disfignrement, or anatomical loss affecting one or more of the following body systems: neurological, musculoskeletal, special sense organs, respiratory (includiug speech organs), cardiovascular, reproductive, digestive, genito-urinary, hemic and lymphatic, skin, and endocrine; or

(2) Any mental or psychological disorder, such as mental retardation, organic brain syndroine, emotional or mental illness, and specific learning disabilities.

29 C.F.R. $\S 1630.2(\mathrm{~h})$ (1999) (EEOC regulations); see also 28 C.F.R. $\S 36.104(\mathrm{i})$ (1999) (DOJ regulations).

138. 480 U.S. 273 (1987). Arline was a Rehabilitation Act case in which plaintiff Arline, an elementary school teacher suffering from chronic tuberculosis, alleged she was fired out of fear of contagion. The Supreme Court held that Arline could be considered a "handicapped individual" within the meaning of $\S 504$ of the Rehabilitation Act because her hospitalization for tuberculosis sufficed to establish a record of impairment. See id. at 281. The Court remanded on the question whether Arline was otherwise qualified, that is, whether she posed "significant health or safety risks" to others. Id. at 287. Arline played a seminal role in the drafting of the ADA and its implementing regulations and interpretive guidelines. See, e.g., 29 C.F.R. \$ 1630.2(1) (app. 352) (1999) ("The rationale for the 'regarded as' part of the defmition of disability was articulated by the Supreme Court in the context of the Rehabilitation Act of 1973 in School Board of Nassau County v. Arline."). 
reactions to actual or perceived handicaps with actions based on reasoned and medically sound judgments. ${ }^{139}$

According to Justice Brennan's logic, perceived impairments can have handicapping effects just as severe as those caused by actual physical impairments. The locus of limitation is immaterial: Whether the limitation arises from an individual's own body or from "society's accumulated myths and fears about disability and disease," it debilitates just the same. Accordingly, the first prong of the ADA's disability definition addresses actual physical and mental impairments whereas the second and third prongs focus on perceived disabilities, whether actual or "mythical."

Although the actual impairment prong of the definition is analytically distinct from the other two, the "record of" and "regarded as" prongs relate back to the first prong in their reference to "such an impairment" (that is, one that substantially limits a major life activity). ${ }^{140}$ To know whether an individual has a "record of" or is "regarded as" having "such an impairment," we must first determine what "such an impairment" would mean for an AIDS vaccine recipient. A false-positive HIV blood test, although incorrect, may arguably constitute a record of infection with HIV. As the EEOC regulations construing the defimition state: "Has a record of such impairment means has a history of, or has been misclassified as having, a mental or physical impairment that substantially limits one or Inore major life activities." ${ }^{141}$ Assuming arguendo that a false-positive test "misclassifies" an individual as HIV-positive, the question then becomes: Is HIV infection a physical impairment that substantially limits one or inore inajor life activities?

The analysis follows a similar trajectory under the "regarded as" prong. Assuming that an employer or other decision maker has learned about a plamtiff's apparent HIV-positive status, and assuming that the employer or decision maker "treats"142 the plaintiff adversely based on the impression that he or she is actually infected with HIV, the analysis agam turns on the definition of "such an impairment." Did the employer or

139. Arline, 480 U.S. at 284-85. Although the language cited has obvious implications for people with AIDS, the Court carefully limited its holding:

This case does not present, and we therefore do not reach, the question whether a carrier of a contagious disease such as AIDS could be considered to have a physical impairment, or whether such a person could be considered, solely on the basis of contagiousness, a handicapped person as defined by the [Rehabilitation] Act.

Id. at 283 n.7. As discussed infra, the question identified but left unanswered in Arline was addressed in Bragdon v. Abbott, 524 U.S. 624 (1998) (holding, inter alia, that HIV is an impairment from the moment of imfection).

140. See Bragdon, 524 U.S. at 658 n.I (Rehnquist, C.J., concurring im part and dissenting im part).

141. 29 CFR. $\$ 1630.2(\mathrm{k})$ (1999) (second emphasis added).

142. The EEOC regulations offer three alternative readings of the "regarded as" prong. The third is relevant in this context: "Is regarded as having such an impairment means... [h] has none of the impairments defined ... but is treated by a covered entity as having a substantially limiting impairment." 29 C.FR. $\$ 1630.2(1)(3)$. 
relevant decision maker regard the plaintiff as having an impairment that substantially limits a major life function? The outcome depends on whether HIV infection substantially limits a major life function. ${ }^{143}$ As discussed in the next Section, this was precisely the question presented in Bragdon.

\section{B. Bragdon v. Abbott and Asymptomatic HIV Infection}

In Bragdon, ${ }^{144}$ the U.S. Supreme Court granted certiorari on the following question: "[W] hether HIV infection is a disability under the ADA when the infection has not yet progressed to the so-called symptomatic phase."145 The facts of the case were simple. Plaintiff Abbott went to dentist Bragdon for an appoimtment in 1994. She had been infected with HIV since 1986, and she disclosed her HIV status on the dentist's patient registration form. When Bragdon discovered a cavity in the course of his examination of Abbott, he informed her of his policy against filling cavities of HIV-infected patients im his dental office. Bragdon offered to perform the work at a hospital with no added fee for services. Abbott, however, would have to foot the bill for the hospital's facilities, he explained. ${ }^{146}$ Abbott declined and sued Bragdon under state law and the ADA for discrimination in public accommodations. ${ }^{147}$ The U.S. District Court for the District of Maine granted summary judgment for plaintiff Abbott, ${ }^{148}$ and the First Circuit affirmed. ${ }^{149}$

On appeal to the U.S. Supreme Court, Justice Kennedy, writing for a 5-4 majority, held that: (1) HIV is a physiological impairment

143. The EEOC's Interpretive Guidance on Title I of the Americans with Disabilities Act, appended to the implementing regulations, offers an example of this situation that is telling for our purposes:

An individual satisfies ... the "regarded as" definition of "disability" if the employer or other covered entity erroneously believes the individual las a substantially limiting impairment that the individual actually does not liave. This situation could occur, for example, if an employer discharged an employee in response to a rumor that the employee is infected with Human Immunodeficiency Virus (HIV). Even though the rumor is totally unfounded and the individual has no impairment at all, the individual is considered an individual with a disability because the employer perceived of this individual as being disabled. Thus, in this example, the employer, by discharging this employee, is discriminating on the basis of disability.

29 C.F.R.§ 1630.2(1) (app. 352) (1999). The EEOC has been criticized for assuming that HIV infection, in this example, constitutes an "mipairment, much less a disability." Wilson v. Georgia Pacific Corp., 4

F. Supp. 2d 1164, 1170 n.5 (N.D. Ga. 1998).

144. 524 U.S. 624 (1998).

145. Id. at 628 .

146. See id. at 629 .

147. See id. "No individual shall be discrinninated against on the basis of disability in the full and equal enjoyment of the goods, services, facilities, privileges, advantages, or accommodations of any place of public accommodation by any person who owns, leases (or leases to), or operates a place of public accommodation." 42 U.S.C. $\$ 12182$ (a) (1994). The term "public accommodations" is defined by the ADA to include the "professional office of a liealth care provider." Id. $\$ 12181(7)(\mathrm{F})$.

148. See Abbott v. Bragdon, 912 F. Supp. 580 (D. Me. 1995).

149. See Abbott v. Bragdon, 107 F.3d 934 (1st Cir. 1997). 
of the hemic and lymphatic system "from the moment of infection;" 150 (2) reproduction is a major life activity contemplated by the $\mathrm{ADA} ;{ }^{151}$ and (3) Abbott's HIV infection substantially limited her ability to reproduce. ${ }^{152}$ Accordingly, the Court concluded that Abbott was actually disabled under the $A D A .^{153}$ It remanded the case to the First Circuit for further development of the record on the question whether Abbott's HIV infection posed a "direct threat" to the safety of her dentist Bragdon. ${ }^{154}$

The majority opinion in Bragdon is as noteworthy for what it declined to answer as for what it addressed. Because the Court found Abbott actually disabled, it declined to consider whether she would qualify for protection under the "record of" or "regarded as" prongs of the ADA's definition of disability. ${ }^{155}$ For the same reason, the Court also declined to answer the second question presented on appeal, that is "whether HIV infection is a per se disability under the ADA."156 Similarly, the Court refused to address whether analysis of the limitations posed by an individual's impairment should proceed from the individual's status with or without mitigating measures such as medications that keep symptoms im check. ${ }^{157}$ Finally, the Court's tight focus on the major life activity of reproduction left open the

150. Bragdon v. Abbott, 524 U.S. 624, 637 (1998).

151. See id at 638 .

152. See id. at 639. The Court developed two independent paths to this conclusion. The first analyzed potential transmission of HIV to Abbott's sexual partner as a limitation on reproduction. See id. The second focused on the risk of perinatal (mother-to-infant) transmission as such a limitation. See id. at 640 .

153. See id. at 631 .

154. Id. at 655 .

155. "We hold respondent's HIV iufection was a disability under subsection (A) of the definitional section of the statute. In light of this conclusion, we need not consider the applicability of subsections (B) or (C)." Id. at 631 .

156. "Respondent's HIV infection is a physical impairment which substantially limits a major life activity, as the ADA defines it. In view of our holding, we need not address the second question presented, i.e., whether HIV infection is a per se disability under the ADA." Id. at 641-42.

157. Given the procedural posture of the case, that is, summary judgment in favor of plaintiff Abbott below, the Court characterized the issue as a matter of law it did not need to resolve in order to decide the instant case:

The Solicitor General questions the relevance of the $8 \%$ figure [of perinatal transmission of $\mathrm{HIV}$ when the mother is treated with $\mathrm{AZT}$, pointing to regulatory language requiring the substantiality of a limitation to be assessed without regard to available mitigating measures .... We need not resolve this dispute in order to decide this case, however. It cannot be said as a matter of law that an $8 \%$ risk of transimitting a dread and fatal disease to one's child does not represent a substantial limitation on reproduction.

Id. at 640-41. The Court has recently settled this question, fiatly contradicting the regulatory language mentioned by Justice Kennedy, establishing that "disability under the Act is to be determined with reference to corrective measures." Sutton v. United Air Lines, Inc., 119 S.Ct. 2139, 2149 (1999) (holding that severely myopic job applicants must be evaluated with corrective lenses to decide whether they are disabled under the ADA); see also Murphy v. United Parcel Service, Inc., 119 S.Ct. 2133 (1999) (holding that an employee with severe hypertension must be evaluated for disability im medicated condition). See generally The Supreme Court, 1998 Term-Leading Cases, 113 HARv. L. REv. 326, 337-49 (1999) (analyzing the trilogy of ADA cases, mcluding Murphy and Sutton, decided by the Court in its 1998 term). 
question of other major life activities that might be substantially hmited by HIV infection. ${ }^{158}$

\section{Questions Remaining after Bragdon: Are Individuals with a "Record of" HIV Infection or Who are "Regarded as" HIV-Infected Protected by the $A D A$ ?}

The Bragdon decision resolved a notorious split in the circuits. In Runnebaum v. NationsBank of Maryland, ${ }^{159}$ the Fourth Circuit had held that the "plain meaning" of the term impairment, as used in the ADA, "suggests that asymptomatic HIV infection will never qualify as an impairment." 160 Equating the 1misnomer "asymptomatic" with a complete absence of physical effects, the Court reasoned that no limitation could reasonably be found: "[W]ithout symptoms, there are no diminishing effects on the mdividual."161 The First Circuit, on the other hand, took the opposite tack in Abbott v. Bragdon:"162 "We hold unhesitatingly that HIV-positive status, simpliciter, whether symptomatic or asymptomatic, comprises a physical impairment under the ADA." 163

In Bragdon, the Supreme Court expressly overruled the interpretation of impairment articulated in Runnebaum: "HIV infection must be regarded as a physiological disorder with a constant and detrimental effect on the infected person's hemic and lymphatic systems from the inoment of infection. HIV infection satisfies the statutory and regulatory definition of a physical impairment during every stage of the disease." 164 By holding that infection with HIV is a per se impairment, however, the Court did not hold that HIV is a per se disability. In refusing to address whether HIV is a per se disability, the Court implicitly suggested that the inquiry as to substantial limitation of a major life activity should take place on an individualized basis. ${ }^{165}$ The resulting indeterminacy, arising from the fact-specific nature

158. " $[\mathrm{T}] \mathrm{t}$ may seem legalistic to circumscribe our discussion to the activity of reproduction. We have little doubt that had different parties brought the suit they would have maintained that an HIV infection imposes substantial limitations on other major life activities." Bragdon, 524 U.S. at 637. See generally Michelle T. Friedland, Note, Not Disabled Enough: The ADA's "Major Life Activity" Definition of Disability, 52 STAN. L. REv. 171 (1999) (analyzing the disjunction between the ADA's dual goals of encouraging reasonable accommodation and ferreting out discrimination with respect to the major life activities requirement).

159. 123 F.3d 156 (4th Cir. 1997).

160. Id. at 169 .

161. Id. at 168 (citing Webster's Dictionary definitions of "impairment").

162. 107 F.3d 934 (1st Cir. 1997), vacated and remanded, 524 U.S. 624 (1998).

163. Id. at 939. The First Circuit joined the Ninth and Eleventh Circuits in so holding. See Gates v. Rowland, 39 F.3d 1439, 1446 (9th Cir. 1994); Doe v. Garrett, 903 F.2d 1455, 1459 (11th Cir. 1990), cert. denied, 499 U.S. 904 (1991).

164. Bragdon, 524 U.S. at 637.

165. Justice O' Connor stressed this point in her brief opinion: “[R]epondent's claim of disability should be evaluated on an individualized basis and ... she has not proven that her asyinptomatic HIV status substantially limited one or more of her major life activities." Id. at 664 (O'Connor, J., concurring in part and dissenting in part). She has since clarified her reasoning on this point in Sutton $v$. 
of the substantial limitation inquiry, effectively undercuts much of the precedential value of Bragdon.

To illustrate this point, we turn back to our hypothetical AIDS vaccine recipient. If we posit a menopausal female vaccinee, for example, it is not at all certain that she will be protected by the ADA after Bragdon if she tests positive for HIV antibodies. While the Court focused solely on reproduction as a major life activity in Bragdon, ${ }^{166}$ an individualized, factspecific inquiry may reveal that the hypothetical discriminating decision maker did not "regard" the plaintiff as substantially limited in the major life activity of reproduction. Since the decision maker may regard the plaintiff as infertile, and therefore may regard reproduction as an insignificant life activity for the plaimtiff, rightly or wrongly, the decision maker may not regard the plaintiff as substantially limited in a major life activity ${ }^{167}$ A similar hitch upsets the "record of" analysis under this scenario. If a plaintiff inust show that a false-positive blood test constitutes a

United Air Lines, 119 S.Ct. 2139, 2147 (1999) (insisting on individualized inquiry under the ADA and rejecting an approach that "would often require courts and einployers to speculate about a person's condition and would, in inany cases, force them to inake a disability determination based on general information about how an uncorrected inpairment usually affects individuals, rather than on the individual's actual condition.")

166. In Abbott v. Bragdon the First Circuit had held that "HIV-positive status is a physical impairment that substantially limits a fecund woman's major life activity of reproduction." Abbott, 107 F.3d at 942 (emphasis added). This awkward holding has led to speculation about its apphicability to non-fecund women or fecund and non-fecund inen. Compare Wendy E. Parmet \& Daniel J. Jackson, No Longer Disabled: The Legal Impact of the New Social Construction of HIV, 23 AM. J. L. \& MED. 7, 35-36 (1997) (arguing that "the court's conclusion that Ms. Abbott was disabled was based in large part on the fortuity of her own fertility"), with Theresa A. Schneider, Note, Stretching the Limits of the ADA: Asymptomatic HIV-Positive Status as a Disability in Bragdon v. Abbott, 118 S.Ct. 2196 (I998), 77 NeB. L. REv. 206, 221 (1998) (contending that individualized inquiry is necessary to prevent "absurdities" such as gay men or menopausal women basing ADA claims on the major hife activity of reproduction).

167. The issue discussed here was nicely captured in a recent district court case involving a gay male, HIV-positive plaintiff:

Plaintiff asserts that he has wanted to have children since he was nineteen years old .... On the other hand, defendant argues that since plaintiff claims he wanted to father a child since he was nineteen, but did not discover he was HIV-positive until he was 33, and plaintiff did not take any steps to consummate his alleged desire to father a child, this deinonstrates that his subsequent diaguosis of HIV-positive did not substantially himit this activity. In addition, defendant contends that plaintiff cannot denronstrate that his HIV condition substantially limited his ability to reproduce because plaintiff is a sexually active honiosexual nuale, who during the relevant time period, was involved in an exclusively homosexual relationship. Contrary to defendant's arguments, plaintiff's homosexual relationship would not preclude him from fathering a child.

Hernandez v. Prudential Ins. Co. of America, 977 F. Supp. 1160, 1164 (M.D. Fla. 1997). Although plaintiff may be able to father a child, as the court observes, the question here is whether reproduction is a major life activity of plaintiff. As Chief Justice Rehnquist has pointed out, the ADA provides that "the 'unajor life activities' allegedly limited by an impairment must be those 'of such individual." Bragdon, 524 U.S. at 657 (Rehnquist, C.J., concurring in part and dissenting in part) (citing the ADA at $\$ 12102(3)(A)$ ) (emphasis added). Furthermore "the ADA's definition of a disability is inet only if the alleged impairment substantially 'limits' (present tense) a major life activity." Id. at 661. Hypothetical atteinpts to reproduce, hence, are not necessarily pertinent to the analysis. 
record of impairment that substantially limits a major life activity, then, once again, the plaintiff will have to show on an individualized basis that the life activity alleged is "major" for him or her. In short, the Court's selfdescribed "legalistic" circumscription of the major life activity analysis in Bragdon leaves many key questions unsettled for subsequent suits.

The Court is not solely responsible for this continuing annbiguity. The problem also stems from the drafting of the "major life activities" definition in the ADA's implementing regulations: "Major life activities means functions such as caring for one's self, performing manual tasks, walking, seeing, hearing, speaking, breathing, learning, and working." 168 As the Court correctly states, the use of the term "such as" clearly demonstrates that the list is intended to be "illustrative, not exhaustive." 169 This is why the Court is free to consider whether reproduction qualifies as a major life activity even though it does not appear on the list. The trouble with an "illustrative" list, however, is that there is no articulated primciple allowing lower courts to determine which activities qualify as major life activities. ${ }^{170}$ On the one hand, the illustrative list allows room to construe the term "major life activities" liberally. On the other hand, uncertainty in construction reigns until a new major life activity has been anointed by the Supreme Court.

The upshot of the Court's constrained holding im Bragdon is readily apparent. An HIV-positive "fecund woman," as the First Circuit clinically put it, is now clearly protected by the ADA as actually disabled. Is there any legitimate reason why HIV-infected infertile women or nonprocreating men should not be equally certain of their protection by federal disability law? Is one any less disabled by HIV simply because one does not presently reproduce? By treating all sexual activity under the rubric of reproduction, as if all sexual activity capable of transmitting HIV were procreative in nature, the Court draws an artificial line. On one side of this line fall fecund women, and on the other side falls everyone else. In explaining why reproduction qualifies as a major life activity, Justice Kennedy writes: 'Reproduction and the sexual dynamics surrounding it are central to the life process itself." 171 Although a subtle parochialism, this strong association of sex with reproduction narrows the field of sexuality considerably. For instance, anal and oral sex are not necessarily "sexual

\footnotetext{
168. 28 C.F.R. § 41.31(b)(2) (1998); 29 C.FR. \& 1630.2(i) (1999).

169. Bragdon, 524 U.S. at 639.

170. The EEOC's interpretive guidance does not help significantly:

'Major life activities' are those basic activities that the average person in the general population can perform with little or no difficulty. Major life activities include caring for oneself, performing manual tasks, walking, seeing, hearing, speaking, breathing, learning, and working. This list is not exhaustive. For example, other major life activities include, but are not limited to, sitting, standing, lifting, reaching.

29 C.F.R. § 1630.2(i) (app. 349) (1999).
}

171. Bragdon, 524 U.S. at 638 . 
dynamics surrounding [reproduction]." Justice Kennedy's analysis thus constrains the activity of sex to reproductive sex without ever asking whether non-procreative sex constitutes a major life activity.

The bright line drawn by the Court, moreover, does not appear so bright when it comes to the "record of" and "regarded as" prongs. By declining to reach Abbott's claims under these theories, the Court left the analysis of perceived disabilities, as described by Arline, entirely vague. Although we now know that HIV, whether symptonatic or asymptomatic, qualifies as a physical impairment, we do not know how the perception of such an impairment by a decision maker should be treated. Is it enough that the defendant regards the plaintiff as HIV-positive? Or inust the defendant regard the plaintiff as HIV-positive and therefore impaired in her ability to reproduce? ${ }^{172}$ If the plaintiff cannot demonstrate by record evidence that reproduction is a present major life activity for her, does this preclude a finding of disability after Bragdon ? $^{173}$ Or is the relevant decision maker's perception of the significance of the life activity to the plaintiff dispositive? Given the conflict between the plain language of the ADA, the interpretive guidance offered by the agencies charged with impleinenting it, and the Supreme Court's "miserly construction"174 of the Act, such questions can be multiplied indefinitely.

\section{V}

\section{Statutory and Regulatory Responses: Minimizing Social Harms TO AIDS VACCINE RECIPIENTS}

\section{A. Disability Discrimination Law as a Poor Fit for Research Subjects}

As discussed in Part IV, the Supreme Court's holding in Bragdon does not sufficiently settle the construction of the ADA's definition of disability to grant AIDS vaccinees any reasonable measure of security in the face of prospective social harms. ${ }^{175}$ A false-positive HIV test may or may

172. Chief Justice Rehnquist apparently views this as the correct inquiry: "Respondent has offered no evidence to support the assertion that petitioner regarded her as having an impairment that substantially limited her ability to reproduce, as opposed to viewing her simply as impaired." Id. at 658 n.1 (Rehnquist, C.J., concurring in part and dissenting in part).

173. Again, this seems to be the Chief Justice's opinion: "[T]here is not a shred of record evidence indicating that, prior to becoming infected with HIV, respondent's major life activities included reproduction." Id. at 658.

174. Sutton v. United Air Lines, 119 S.Ct. 2139, 2152 (1999) (Stevens, J., dissenting). Ruth Colker has similarly criticized the courts for treating the ADA parsimomiously: "[D]efendants prevail in more than ninety-three percent of reported ADA employment discrimination cases decided on the merits at the trial court level. Of those cases that are appealed, defendants prevail in eighty-four percent of reported cases." Ruth Colker, The Americans with Disabilities Act: A Windfall for Defendants, 34 HARV. C.R.-C.L. L. REv. 99, 100 (1999) (citations omitted). Colker further argues that courts have abused the summary judgment device in ADA hitigation. See id. at 101

175. Even if we assume that the "regarded as" and "record of" analysis would conclude favorably in those jurisdictions where HIV infection has been deemed a per se disability for ADA purposes (that is, in the First, Ninth, and Eleventh Circuits), the lack of uniformity across the circuits renains a cause 
not lead to liability if used against a given plaintiff. Without a stronger sense of the scope of protection afforded by the ADA, AIDS vaccine trial participants cannot rely on the Act to shield them from discrimination based on vaccine seropositivity. More significantly, disability law does not extend to discrimination based on AIDS vaccine trial participation. Many of the high-risk behaviors required for participation in vaccine trials, such as prostitution, illicit drug use, and sodomy, are themselves illegal in many states. It would be anomalous indeed if federal disability law prevented "discrimination" against individuals for behavior that would otherwise subject them to criminal sanction. ${ }^{176}$ In short, disability law seems poorly suited to cover the myriad adverse situations vaccinees may face as a result of their participation in experimental trials.

If this Comment has focused seemingly inordinate attention on the inadequacy of federal disability law as a potential source of protection for AIDS vaccine trial participants, it is because inuch of the extant literature uncritically assumes that ADA protection extends to asymptoinatic HIV infection. One scholar writes: "As a result of the Bragdon decision, individuals inay feel less hesitant about submitting to testing for the HIV virus because now they can feel confident that, if they are HIV-positive, they are protected from discrimination by the ADA."177 Another stateinent carries the same import and extends it to perceived infection: "[D]iscrimination on the ground of HIV seropositivity-or even suspicion that an individual is HIV-seropositive-is now illegal in many circuinstances." ${ }^{178}$ Even President Clinton's National AIDS Strategy statement wishfully overstates the scope of federal disability law, inentioning among the White House's

of grave concern. See Michael D. Carlis \& Scott A. McCabe, Comment, Are There No Per Se Disabilities Under the Americans with Disabilities Act? The Fate of Asymptomatic HIV Disease, 57 MD. L. REv. 558, 614 (1998) (arguing that "Congress surely did not intend individuals with HIV disease, symptomatic or asymptomatic, to fall outside the Act's protection").

176. The criminalization of sodomy between consenting adults has raised interesting constitutional disputes. In Bowers v. Hardwick, 478 U.S. 186 (1986), the Supreme Court upheld against due process attack the constitutionality of a Georgia statute outlawing homosexual sodomy. Nevertheless, as Cass Sunstein has famously argued, "a class that includes people who engage in acts substantively unprotected by the Due Process Clause can be entitled to judicial protection against official discrimination" under the Equal Protection Clause. Cass R. Sunstein, Sexual Orientation and the Constitution: A Note on the Relationship Between Due Process and Equal Protection, 55 U. CHI, L. REv. 1161, 1168 (1988). The Supreme Court appears to have endorsed this view. See, e.g., Romer v. Evans, 517 U.S. 620 (1996) (striking down, on equal protection grounds, a Colorado state constitutional amendment burdening homosexuals as a class). Since the entry criteria for AIDS vaccine trials focus on behavior (sodomy) rather than status (homosexuality), trial-relatcd discrimination potentially raises questions within the contested space between Bowers and Romer. Justice Scalia, for one, beheves that Romer is flatly imconsistent with Bowers. See id. at 640-41 (Scalia, J., dissenting). Thus, it remains to be seen whether the constitutionality of laws proscribing homosexual sodomy survives Romer.

177. Christine Spinella Davis, Comment, Asymptomatic HIV Under the ADA: The Invisible, Yet Legitimate Disability, 15 J. Contemp. Health L. \& PoL'y 357, 399 (1998).

178. GRAY ET AL., supra note 52, at 11. 
accomplishments "[e]nactment of the Americans with Disabilities Act of 1990 (ADA), which protects individuals living with HIV and AIDS and people perceived to be at risk for HIV from discrimination in housing, employment, and public accommodation." 179

Why do such overstatements of the protections afforded by federal disability law really matter in the context of AIDS vaccine research? The answer lies in the risk/benefit calculus a potential vaccine trial subject will perform in deciding whether or not to participate. Scott Burris has advanced a useful notion of "reliance" in the context of HIV testing that is helpful when thinking about vaccine trials:

Theories about compliance might explain why the ADA prevents a dentist from discriminating against a patient with HIV, and disputing theory will explain why most victims of this sort of discrimination do not sue, but neither addresses the question of why and how a person who is protected by law and who wishes to avoid an imjury will imtegrate the law into a prospective decision to run the social risk of testing. For this, I suggest, we need a new concept, which I am calling "reliance." 180

Like someone deciding to get tested for HIV, a potential AIDS vaccine trial participant might make the "prospective decision to run the risk" of trial participation by integrating inisstatements of the law into their decisionmaking process. "Reliance," in this case, leads to unfounded security. When researchers, who are not legal experts, incorporate broad statements about protection against discrimination such as those cited above into their consent procedures, trial participants might underestimate their risk of social harm. In this way, informed consent potentially shades imto misinformed consent. ${ }^{181}$ "Reliance" on unsettled law may lead, unsettlingly, to questionable voluntarism.

179. NATIONAL AIDS Strategy, supra note 19, at 27 (emphasis added).

180. Scott Burris, Law and the Social Risk of Health Care Lessons from HIV Testing, 61 ALB. L. REv. 831, 835 (1998).

181. As part of the informed consent process, for example, a number of research entities in the San Francisco Bay Area distribute to potential AIDS vaccine trial participants a brochure prepared by the AIDS Legal Referral Panel (ALRP) entitled The Rights of HIV Vaccine Trial Participants. The brochure contains the following advice concerning potential employment discrimination:

As a person who is vaccine positive but not HIV infected, it is unlikely that you will be considered "disabled" under [the ADA], where it is defined as a physical or mental impairment that substantially limits one or more major life activities. But [the ADA] also protect[s] a person who is "regarded as having such an impairment." In other words, if you are discriminated against because your employer presumes you to be HIV infected, you would be entitled to the full protection of [the ADA] as if you were actually HIV infected.

ALRP, The Rights of HIV Vaccine Trial Participants 4 (1997) (citations omitted). This misleadingly optimistic characterization of the law was picked up by another recent handbook: "The San Francisco-based AIDS Legal Referral Panel has noted that U.S. law may protect individuals from discrimination based on perceived HIV status resulting from HIV vaccine trial participation. This protection coines, im part, under the Americans with Disabilities Act." AIDS VACCINE ADvocACY 
I do not mean to suggest that researchers and study recruiters are intentionally disseminating false or misleading statements of the law to dupe prospective participants. I am, however, argumg that the legal issues raised by AIDS vaccime trial participation are complex and easily susceptible to misstatement. In addition, I am arguing that optimistic reliance on legal protections afforded by disability law can lead to uninformed decisionmaking when it comes to AIDS vaccine trial participation. In short, the social harm issues posed by AIDS vaccine trials go far beyond the bounds of disability discrimination law. They miplicate the very foundational notions of human experimentation itself: Respect for the autonomy of persons, beneficence, and justice. ${ }^{182}$ These overarching principles must be taken imto account in addressing the unique social challenges of AIDS vaccme research.

\section{B. The Inadequacy of State-Initiated Protection Schemes}

Apart from federal disability discrimination law, what other sources of legal protection are available to trial participants? Very few state governments have addressed the issue. ${ }^{183}$ California has taken the national lead in promulgating laws to accelerate production of a safe, effective AIDS vaccine. In 1983, the Golden State initiated a comprehensive legislative effort to address the AIDS crisis. ${ }^{184}$ As part of this scheme, which mcludes provisions for an AIDS vaccine victimus compensation fund, ${ }^{185}$ an ADS

Coalition (AVAC), hiV Vaccine Handbook: Community Perspectives on Participating in Research, AdVocacy, AND Progress (Bill Snow ed., 1999) [hereinafter HIV Vaccine HaNdBOoK].

182. These three basic ethical principles were articulated by the National Commission for the Protection of Human Subjects of Biomedical and Behavioral Research in the famous Belmont Report of 1976. See Dennis M. Maloney, Protection of Human Research Subjects: A Practical Guide to Federal Laws aNd Regulations 31-40 [hereinafter Belmont REPORT]. Dr. Harold Varmus, Director of the National Institutes of Health (NIH), has called these principles "the three quintessential requirements for the ethical conduct of research involving human subjects." Testimony of Harold $E$. Varmus, M.D., Director, National Institutes of Health, Before the Subcommittee on Human Resources and Intergovernmental Relations Committee on Government Reform and Oversight, U.S. House of Representatives, in II BIolaw: Updates and Special Sections S:343 (October 1997). My thinking about the ethics of human research has heen guided by the seminal text on the topic, JAY KATZ, Experimentation with Human BeIngs (1972).

183. Connecticut has passed legislation designed to foster research into AIDS vaccines. See ConN. Gen. STAT. $\$ \S 19 a-590-19 a-591 c$ (1991). Connecticut's approach is to limit research liability to cases of "gross negligence or reckless, wilful or wanton misconduct," id. § 19a-591b, provided that the research subject has been given a "written explanation" of the limitation and "informed consent" is secured before administration of an AIDS vaccine, id. $\S 19 \mathrm{a}-591 \mathrm{a}$. Connecticut does not indicate whether foreseeable trial-related social harms must be disclosed as part of the informed consent process.

184. See CAL. HeALTH \& SAFETY CODE $\S \S 121200-121280$ (West 1996). The history and relevant baekground of the Califorma AIDS Initiative is helpfully recounted in Margaret Salmon Rivas, The California AIDS Initiative and the Food and Drug Administration: Working at Odds with Each Other?, 46 FOOD DRUG \& CoSM. L.J. 107 (1991); see also Wilson, supra note 6, at 556-59.

185. See CAL. HeAITH \& SAFETY CODE § 121270 (1999). 
vaccine guaranteed purchase fund, ${ }^{186}$ and an AIDS Vaccine Research and Development Advisory Committee, ${ }^{187}$ California law also offers limited protection against research-related social harms.

California's legislation, however, is severely limited in key respects. The California Health and Safety Code provides in relevant part: "No health care service plan, disability insurer, nonprofit hospital service plan, self-insured einployee welfare benefit plan, or life insurer may withhold any settlement or coverage of an individual solely because of his or her participation in an ADSS/HIV vaccine climical trial."188 This language is deceptively reassuring for several reasons. First, although it appears to confer broad protection against trial-related discrimination in the insurance domain, it eliminates coverage for mixed-nnotive discrimination by including the words "solely because of." For example, an insurer could easily claim that its choice not to cover a vaccinee was not "solely because of" trial participation; instead, the reason proffered might be that trial participants are, by definition, at heightened risk of HIV infection. Since trial participation correlates significantly with risky behavior such as injection drug use, a rational insurer would be remiss if she did not take this evidence of risk into account. Second, large einployers, who are generally self-insured, are substantially exempted from state regulation of their insurance plans by the preemptive sweep of the Employee Retirement Incoine Security Act of 1974 (ERISA). ${ }^{189}$ Third, protections afforded to trial participants in California are largely unavailable in other states. This means that trial subjects injected in California remain unprotected when they leave the state. It also means that trial subjects mjected in states other than California remain unprotected everywhere but in California. Fimally, the California statute is confined to the realm of insurance; it does not address the myriad other contexts in which trial-related disparate treatment might arise. The upshot is that state-initiated ineasures, though wellmeaning, substantially fail to advance AIDS vaccine research. The inadequacies of state ineasures ${ }^{190}$ coupled with the shifting demographic patterns of the disease, highlight the need for a decisive federal response.

186. See id. \$ 121275 .

187. See id. $\S 121260(f)$.

188. Id. $\$ 121280(4)(b)$.

189. 29 U.S.C. $\$ \S 1001-1191 \mathrm{c}$ (1999). See Jana K. Strain \& Eleanor D. Kinney, The Road Paved with Good Intentions: Problems and Potential for Employer-Sponsored Health Insurance under ERISA, 31 LoY. U. CHI. L.J. 29, 29 (1999) (noting that ERISA "precludes the states from regulating employer-sponsored health plans covered by ERISA"). See also Nancy R. Mansfield, Evolving Limitations on Coverage for AIDS: Implications for Health Insurers and Employers Under the ADA and ERISA, 35 ToRT \& INS. L.J. 117, 117-18 (1999) (arguing that ERISA created a "loophole" in state insurance regulation that allows self-insured employers to cap or eliminate coverage for a particular disease, resulting in the the increasing "medicaidization" of AIDS).

190. John Wilson has also underscored the inadequacy of state schemes to address the AIDS vaccine problem: "While in many instances the piecemeal development of law in the separate states permits each state to craft its own solutions to particular needs, uniform national legislation is still the 


\section{Crafting a Viable Federal Plan}

\section{AIDS Vaccine Research Legislation}

In 1988, Congress declared AIDS a national emergency and authorized funds for research and public information efforts. ${ }^{191}$ The epidemic affects every state, and the search for a safe, effective vaccine surely qualifies as a national interest. I therefore concur with John Wilson's conclusion that "a way must be found to limit manufacturer concerns about liability yet provide timely and adequate compensation to injured vaccinees. Federal legislation is the best way to achieve this goal."192 Accordmgly, the first step in addressing the AIDS vaccine effort should be to map out a coordinated national agenda.

Much ink has already been spilled in devising injury compensation schemes and federal tort relief for biotechnology and pharmaceutical companies. ${ }^{193}$ Virtually none of the literature addresses social harm to trial participants; rather, the focus has been almost exclusively on protecting pharmaceutical and biotechnology coinpanies from crushing liability so as to accelerate research and development of candidate vaccines. ${ }^{194}$ As an initial matter, then, the federal government should develop a balanced legislative program akin to the one incipiently spelled out in California, that is, a program that addresses the needs of coinpanies as well as the needs of those who participate in research as subjects.

Representative Nancy Pelosi and Senator John Kerry recently introduced a bill, entitled "The Lifesaving Vaccine Technology Act of 1999," that would provide a thirty percent tax credit to biotechnology and pharmaceutical companies for qualified research and development expenditures on vaccimes for malaria, tuberculosis, $\mathrm{HIV}$, and other diseases that kill one million or more people annually. ${ }^{195}$ This is a laudable first step, and

preferred route when dealing with a crisis of national-indeed, international-dimensions." Wilson, supra note 6 , at 562 .

191. See AIDS Amendments of 1988, Title II of Pub. L. No. 100-607, 102 Stat. 3062-3111 (codified principally in scattered subsections of 42 U.S.C. $\$ 300$ ); Rhonda McMillion, Towards a National AIDS Policy, ABA J., July 1, 1988, at 123.

192. Wilson, supra note 6 , at 569.

193. See discussion supra note 6 and accompanying text.

194. As discussed supra note 6 , tort relief and injury compensation schemes have almost uniformly disregarded social harms as a factor in AIDS vaccine research. For example, in a subsection entitled "What kind of injury should be compensated?" Catherine Polizzi restricts consideration to "serious, acute, systemic injury, such as anaphylactic shock or neurological disorders." Polizzi, supra note 6 , at 20. Although she considers extending coverage to "development of AIDS after vaccination," Polizzi quickly decides against it because "this potentially broad coverage could drastically increase the cost of the program due to the extensive and prolonged medical care required by AIDS." Id. at 21. Polizzi's proposal is representative in this respect. Social harms rarely even appear on the radar screen of potentially compensable harms.

195. See H.R. 1274, 106th Cong. (1999); S. 1718, 106th Cong. (1999); see also Tom Abate, Should Vaccine Research for HIV Merit a Corporate Tax Break? Pelosi-Sponsored Bill May Wind Up Being a Pandora's Pork Barrel, S.F. ChroN., Apr. 5, 1999, at E1; Judy Holland, Pelosi Seeks 
political leaders in both parties should take up the cause. Although the proper size of the credit can be debated, it should be beyond partisan cavil that "achieving effective and affordable vaccines for HIV, inalaria, and tuberculosis will yield public benefits beyond those benefits captured by the manufacturer." 196

While I agree with the general strategy incentivizing private sector research and development of vaccines, this can only be a first step in the process. Companion legislation inust be drafted that will broadly outline the responsibilities of the research entities receiving these substantial tax credits. Since the trial of ADS vaccmes raises unique challenges, these anomalies must be addressed. At a minimum, participating entities should be required to do the following:

- Voluntarily submit to regulation and oversight by an expanded Office for Prevention of Research Risks (OPRR); ${ }^{197}$

- Guarantee that any successful vaccine product will be inade freely available to those who have participated im clinical trials;

- Make blood assays capable of distinguishing HIV infection froin vaccme-mduced antibody response available to participants for life;

- Provide for risk-reduction counselling to participants throughout the trials, emphasizing that experimental vaccines will not confer protective immumity aganist HIV infection;

- Implement an agency-approved system of confidentiality protections to prevent disclosure of the fact of trial participation and trial data, especially blood testing resnlts; ${ }^{198}$

Subsidies for AIDS Vaccine Effort; Tax Credits Would Spur Companies to Make Low-Profit Drugs, She Says, S.F. ChroN., July 6, 1999, at A7. Senator Kerry has recently introduced a more comprehensive version of the bill under the new title "Vaccines for the New Millennium Act of 2000." See S. 2132, 106th Cong. (2000).

196. S. $2132 \S 2(11)$. President Clinton recently signaled his approval of the Pelosi/Kerry approach in his state of the union address. See President William J. Clinton, State of the Union Address, January 27, 2000 (visited Feb. 2, 2000) <http://www.whitehouse.gov/WH/SOTU00/sotu-text.html> ("I propose a tax credit to speed the development of vaccines for diseases like malaria, TB and AIDS. I ask the private sector and our partners around the world to join us im embracing this cause. We can save millions of lives together, and we ought to do it.").

197. OPRR is currently located in the National Institutes of Health, but HHS Secretary Donna Shalala has directed that that OPRR be relocated to the Office of Public Health and Science within the Office of the Secretary of HHS in order to "elevate its stature and effectiveness." HHS, Protecting Research Subjects (last modified Nov. 4. 1999) <http:www.hhs.gov/news/press/1999pres/991104c. $\mathrm{html}>$. Currently, researcl funded by states and private entities may be conducted without regulation by federal agencies, a proposition that has drawn intensifying criticism. See, e.g., Jonathan Moreno et al., Updating Protections for Human Subjects Involved in Research, 280 JAMA 1951, 1954 (1998) (arguing, inter alia, that it is "striking and unacceptable that there is no universal statutory requirement for informed consent to research irrespective of funding source").

198. HHS recently promulgated proposed regulations to enhance the confidentiality of electronic patient records that could serve as a useful model for experimental research. See Standards for Privacy of Individually Identifiable Health Information, 64 Fed. Reg. 59,918-60,065 (to be codified at 45 C.F.R. pts. 160-164) (proposed Nov. 3, 1999). 
- Recognize an express right to compensation for unconsented disclosure of confidential trial information (including the fact of trial participation, trial-related communications, and test results) based solely on the fact of disclosure itself-unlike a "regarded as" claim under the $\mathrm{ADA}$, the claimant would be required to prove neither adverse action taken by a third party based on the disclosure nor the state of mind of the disclosing party;

- Set up a compensation fund or secure liability coverage sufficient to compensate for injuries fairly traceable to the product or to the negligence, recklessness, or intentional malfeasance of clinicians administering them; ${ }^{199}$

- Agree to submit all claims for compensation to binding arbitration or agency adjudication, with provision for such a nnode of dispute resolution clearly spelled out in the informed consent process.

Once these minima are established by statute, ongoing regulation and oversight should be supplied by the agency charged with implementation, most likely OPRR within HHS, as discussed below.

Suppleinenting this entity-regulating scheme, additional legislation must be introduced to reduce the risk of social harms to vaccine recipients more generally. This legislation could draw on various legislative precedents, but it should:

- Expand the role of OPRR, granting it the power to promulgate regulations and guidelines governing AIDS vaccine research after notice and comment from the agencies imvolved, affected industries, researchers, community based organizations, targeted populations, and other interested parties;

- Create an ombudsman in OPRR specifically charged with responsibility for advocatimg on behalf of vaccinees, providing them with legal advice as to their rights, litigating select cases on their behalf, filing amici curiae on relevant matters, and providing legislative policy

199. John Wilson has suggested, as an alternative, a liability scheme based on the National Childhood Vaccine Injnry Act, 42 U.S.C. $\$ \S 300 \mathrm{a}-1$ to-34 (1988):

A victim would be required first to inake a claim for coinpensation from a fund established by the federal government ... and an award from this fund would be based upon the fact of injury and not the manufacturer's behavior. Only after the receipt of compensation, or the denial thereof, would a state claim be permitted against a manufacturer, and an election at that point (to accept the judgment or file a civil action) would be required. In the application for compensation from the government, an injured vaccinee would have to prove injury and, presumably, causation by a preponderance of the evidence and, as is the case under the National Childhood Vaccine Injury Act, that there is not a preponderance of evidence that the illness or disability is unrelated to the administration of the vaccine.

Wilson, supra note 6 , at 564 . While I am comfortable entertaining the notion of a federally administered compensation system, such as the one Wilson describes, I believe that research entities should provide compensation through a private fund or liability insurance in the absence of such a program. 
support to aid Congress in adjusting the statute, where needed, as trialrelated issues arise;

- Incentivize research and developinent of more sophisticated blood screening inechanisins to distinguish natural infection from vaccine response in parallel with pre-clinical and clinical evaluation of candidate vaccines;

- Mandate that entities performing blood tests, in particular hospitals, laboratories, and insurance companies, shall not disclose the fact of vaccine seropositivity to einployers, insurers, or other entities, instead reporting only that a test is either positive or negative for HIV;

- Craft a system whereby trial participants can self-identify as such solely for the purpose of diagnostic blood tests, so that specialized assays can be employed in a cost-effective inanner;

- Prohibit use of the fact of vaccine positivity or participation in an AIDS vaccine trial as a basis for disparate treatment in employment, in any federally funded or operated program, or as a reason for denial or limitation of insurance coverage; ${ }^{200}$

- Make evidence of vaccine trial participation inadmissible at trial for criminal acts, as a basis for denial of a visa or immigration, or as a basis for adverse einployment action, imcluding failure to hire or promote, in any federal or state agency or department;

- Redouble efforts to educate the American public about the prevalence of ADS worldwide, the principle modes of transmission, the limitations of antiretroviral therapies, the need for continued prevention, and the myths about people living with HIV/ADS and contagion.

These and many other bold legislative solutions to the dilemma of social harms must be devised, debated, and implemented. Protection of human subjects inust keep pace with accelerated research. This is especially true as the federal government wields its taxing power to incentivize research mitiatives in the private sector because private money then becomes indistinguishable froin public subsidies.

\section{Enhanced Regulatory Oversight of AIDS Vaccine Research}

While legislators should paint with a broad brush, the details of implementation should be left to the administrative bodies responsible for enforceinent since they have scientific expertise and are more closely connected to our nation's research imstitutions. The current system for administrative oversight of human experimentation is based on a network of local Institutional Review Boards (IRBs) concurrently regulated by the FDA and

200. Vaccine seropositivity might be treated in the same way that genetic information has been treated for insurance purposes. See, e.g., 29 U.S.C. $\S 1181(b)(1)(B)(1999)$ (restricting the use of genetic information as a preexisting condition exclusion "in the absence of a diagnosis of the condition related to such information"). 
HHS. ${ }^{201}$ HHS regulations apply only to human subjects research "conducted, supported or otherwise subject to regulation"202 by federal departments or agencies that have adopted the so-called "common rule."203 Institutions subject to these regulations must sign prospective "assurances" of compliance with the requiremeuts set forth in the regulations, including the establishment of an IRB to review and monitor research protocols. ${ }^{204}$ The FDA, by contrast, employs a system of retrospective audits and inspections to ensure that all research involving products regulated by the FDA lias complied with its requirements, mcluding in most cases IRB review and monitoring. ${ }^{205}$

The IRB system jointly overseen by HHS and the FDA has recently received increasingly harsh criticism. ${ }^{206}$ Six areas of particular concern have been identified: (1) IRBs face major changes in the research environment; (2) IRBs conduct minimal continuing review of approved research; (3) IRBs review too much, too quickly, and with too little expertise; (4) neither IRBs nor the agencies overseeing them devote sufficient enıphasis to evaluating IRB effectiveness; (5) IRBs face conflicts that threaten their independence; and (6) IRBs and their institutions provide little training for investigators and board members. ${ }^{207}$ Other commentators have emphasized that IRBs need to establish stronger ties with their experimental populations so as to understand and address their nost vital concerns. ${ }^{208}$

IRB underperformance clearly lies beyond the scope of this Comment; however, the weaknesses inherent in the current IRB system are likely to be magnified by the unique scientific and social demands of AIDS vaccme research discussed above. Enhanced administrative oversight will play a crucial role in the evolution of a safe, effective AIDS vaccine. When

201. See 21 C.F.R. pt. 56 (FDA regulations governing IRBs); 45 C.F.R. pt. 46 (HHS regulations governing IRBs). The IRB regulations provide that IRBs shall have "at least five members of varying background," 45 C.F.R. $\$ 46.108$ (a). The IRB must have at least one member whose "primary concems are in scientific areas and at least one member whose concerns are in non-scientific areas." Id. $\S$ 46.108(c). In addition, at least one member "must not be affiliated with the institution." Id. $\$ 46.108$ (d). IRB members are usually "doctors, scientists, patient representatives and others who are cbarged with regularly monitoring the desigu, development and progress of the research projects being conducted at the institution." HHS, supra note 197.

202. 46 C.F.R. $\S 46.101$.

203. Federal Policy for the Protections of Human Subjects, 56 Fed. Reg. 28,003-28,032 (1991).

204. See 46 C.F.R. \$ 46.103 .

205. See 21 C.F.R. \$ 56.103.

206. See Hearing on Institutional Review Boards (IRBs): A System in Jeopardy?, II BIolaw S:295, 298-301 (July-Aug. 1998) (testimony of George Grob, HHS Deputy Inspector General for Evaluation and Inspections).

207. See id.

208. See, e.g., Marjorie M. Shultz, Legal and Ethical Consideration for Securing Consent to Epidemiologic Research in the United States, in ETH1cs AND EP1DEMIologY 107 (Steven S. Coughlin \& Tom L. Beauchamp eds., 1996) (arguing that IRBs need "to get a broad and deep, rather than tokcn, response about risk and consent from the types of people who are likely to populate research studies"). 
combined with truly comprehensive AIDS vaccine legislation and supporting regulations, snch oversight will protect the physical and social well-being of research participants. Specifically, a newly expanded OPRR should undertake the following:

- Promulgate regulations and guidelmes goveruing appropriate recruitment and screening techniques for AIDS vaccine trial cohorts, informed consent procedures and documents, participant confidentiality, provision of risk-reduction counselling, access to product-specific blood assays, and researcher responsibilities upon termination of trials;

- Mandate that IRBs considering the recruitment, trial design, protocol drafting, informed consent procedures, implementation, and oversight of ADS vaccine trials include an individual who will be vaccinated;209

- Require that Community Advisory Boards (CABs) ${ }^{210}$ be established with trial participants, inembers of targeted cominunities, and representatives from community based organizations to provide con1inunity perspectives on all trial-related matters to researchers, IRB ineinbers, trial participants, and involved agencies;

- Assemble and disseminate educational inaterials and provide on-site trainings for IRBs concerning the physical and social risks inherent in AIDS vaccine trials-such inaterials and presentations should einphasize that potential social harms are to be factored into the calculus of risks and benefits for approval and oversight of study protocols. ${ }^{211}$

209. IRB regulations presently include special provisions for research in vulnerable populations such as preguant women, 45 C.F.R. $\S 46.207$, children, id. $\S 46.408$, and prisoners, id. $\S 46.305$. IRBs are required to include a prisoner in reviewing any human subjects research involving prisoners. See id. $\S 46.304$.

210. Although still a germinal concept, CABs should play an increasingly prominent role in the conduct of AIDS vaccine trials from trial design to vaccination and beyond. As Bill Snow observes, the Division of AIDS (DAIDS) already has seven fully operational CABs participating actively in climical trials of AIDS treatments, prevention, vaccines, and in natural history studies of HIV. See Bill Snow, Community Advisory Boards, in HIV VACCINE HANDBOOK, supra note 181, at 149-53. These local $\mathrm{CABs}$ have elected a National $\mathrm{CAB}$ to coordinate conference calls, address issues of concern common to the study sites, and advocate for change through contact with government officials and principal investigators:

Hundreds of times CABs have identified potential problems for investigators ... or helped make trials inore ethical, attractive, and feasible. In addition to their advisory and watchdog function, CABs have helped their communities by disseminating information, arguing the case for volunteering, and reaching people with AIDS and the stigmatized communities that bear the brunt of the epidemic.

Id. at 150 . CABs, and other inechanisms to insure that the input of affected communities is taken into account at every stage of the research process, can provide particularly helpful guidance where social harms issues may arise. They should therefore be mandatory, regardless of whether the study involved is conducted in the private sector, by government-funded entities, or some combination of the two.

211. As the Belmont Report states,

[t] he requirement that research be justified on the basis of a favorable risk/benefit assessinent bears a close relation to the principle of beneficence... Many kinds of possible harms and benefits necd be taken into account. There are, for example, risks of psychological harm, physical harm, legal harm, social harm and economic harm and the corresponding benefits. 
Separate discussion of informed consent ${ }^{212}$ is in order since it is the mainstay of the current regulatory protection of research subjects. As Margaret Johnston and Sam Avrett explain:

The informed consent process should explain the goals of the trial, the reason that the trial would benefit by the participation of the individual, what participation means, the potential risks and benefits of participation to the volunteer and others, alternatives to participation, issues of confidentiality, any compensation for trial participation and for any costs or injuries resulting from trial participation, and the right to end participation at any time. ${ }^{213}$

In addition to these generalized requirements of informed consent, I would stress:

While the most likely types of harms to research subjects are those of psychological or physical pain or injury, other possible kinds should not be overlooked.

BELMONT REPORT, supra note 182 , at 38 . On the spectrum of potential harms that need to be assessed, see KATZ, supra note 182 , at 323-69, 435-62.

212. HHS regulations provide that "no investigator may involve a human being as a subject in research covered by this policy unless the investigator has obtained the legally effective informed consent of the subject or the subject's legally authorized representative." 45 C.F.R. $\$ 46.116$. In her foundational book The Search for an AIDS Vaccine, Christine Grady has suggested that "community informed consent," not simply individual consent, should be secured for research trials:

Conceiving of individuals as inextricably related to and deriving identity from their community gives the individual a stake in research that is good for the community. For vaccine research especially, a system whereby consent to conduct the research was obtained from the "community" and input was obtained from the community about how to conduct it, followed by individual consent from the each of the participant-subjects, should be the ideal. Such a system, in which community members would deliberate together about the ends and methods of research, would give the individual community members some responsibility in supporting the research. Such active participation in deciding the ends and the means promotes the interests of the individual and the community.

GRADY, supra note 7, at 84-85. Grady envisions this "community consent" playing a role at all stages of the trial, starting with preliminary meetings betwecn community leaders and scientists; leading to "town meetings" with researchers presenting the aims and methods of the research to community members to educate and inform them while also seeking their input; and, finally, the community would actually vote on whether the proposed trial should be conducted. Id. at 145 . Once a trial is approved, "[a]n advisory board or working group representative of the community should be created to discuss and negotiate the specifics of protocol design and methods." Id.

Chris Collins, however, has posed trenchant questions regarding Grady's proposal. After praising Grady for her "laudable contribution," Collins notes that embedded in her thinking are "major assumptions about communities," for example,

that their membership is definable and relatively cohesive; that divisions within communities do not prohibit reaching credible decision for all members; that self-perceived membership by trial volunteers in multiple communities will not render decisions by one community illegitimate; and, finally, that communities are comfortable choosing representatives or will be satisfied with a majority vote at a meeting as a valid decision making process for the whole group.

Collins, supra note 7 , at 8 . Collins ultimately concludes that, although "communities may be the ultimate beneficiaries of vaccine research, individual trial volunteers reinain the ultimate arbiters of the merits of a trial." Id. at 9 . Although I am generally sympathetic to the vision Grady advances, I agree with Collins that iuformed consent properly should reniain a matter of individual conscience. As the rest of my proposal should make clear, though, I believe that all of the communities affected by AIDS vaccine research should play an active role in the decision making regarding trials.

213. Johnston \& Avrett, supra note 44 , at 737. 
- That the potential risks and benefits must include social as well as clinical risks and benefits;

- That legal and administrative remedies are available should adverse events occur;

- That a clear, concise explanation of the process for filing researchrelated claims, together with the contact information for the OPRR ombudsman, should be provided;

- That study-related documents, videotapes and other recruitment and consent instruments should be translated into the language of all prospective participants to ensure genunie voluntarism.

Simply put, the "informed consent process should ensure that the potential participant understands the information and that the person's choice to participate or not is voluntary."214

\section{CONCLUSION}

Unfortunately, most discussions of vaccine research schenres have either overlooked social and related harms or consigned them to vague treatment. ${ }^{215}$ President Bush's Commission for the Study of Ethical Problems in Medicine and Biomedical and Behavioral Research, for example, repeatedly stressed the narrow scope of harms that should be addressed by national compensation programs: "Benefits should be provided on a nonfault basis to subjects sustaining nontrivial bodily injuries or death as a result of their participation in covered research."216 The Commission briefly considered social imjuries, but rejected suggestions that they should be compensable:

The Commission understands the term "social injury" to refer to injuries to reputation, personal relationships, or legal status resulting from the disclosure of identifiable personal information gathered in the course of research. The Commission believes that the most serious problems likely to arise in this area (e.g., unauthorized disclosures of sensitive private information) are better handled by a combination of careful prior review of the design of research projects posing such risks and, where necessary, pursuit of legal remedies through the courts. ${ }^{217}$

Social harms, as I have argued, should be factored into the calculus of risks and benefits at every stage of the AIDS vaccine research agenda, not just in trial design and eventual litigation. Although compensation programs for

214. Id.

215. See discussion supra notes $6 \& 194$ and accompanying text.

216. President's Commission for the Study of Ethical Problems in Medicine and BIOMEdical aNd Behavioral Research, COMPENSATING FOR RESEARCh INJURIES A RePORT ON the Ethical and Legal Implications of Programs to Redress InjuRies Caused by Biomedical AND BEHAVIORAL RESEARCH 129 (1982).

217. Id. at 137 . 
trial-related social injuries may present administrative and budgetary challenges, they should not be dismissed without due consideration. ${ }^{218}$ Indeed, if social harms reach a level sufficient to threaten enrollment in Phase III trials, compensation guarantees may present one of the few viable options to facilitate testing of promising candidate AIDS vaccines.

The transition to large-scale doinestic AIDS vaccine trials represents a daunting challenge and a prime opportunity to bring our nation's experiinental research structures iuto the twenty-first century. As the director of the Office for Protection from Research Risks has stated: "This is precisely the time to take constructive account of the notes of caution being sounded and to reform, correct, revise, and inprove the dynamic and evolving system that keeps those who are enrolled in research out of harm's way."219 A coordinated effort-including federal legislation authorizmg limited tort relief for biotechnology and pharmaceutical companies engaged in AIDS vaccine research, a scheme for compensation of trial-related injuries, and enhanced regulatory oversight of the research process addressing not only physical but also social risks to participants in the experimental process-will be a signal achievement and necessary step on the road to a lasting cure for the AIDS pandemic. President Clinton has articulated the vision: "My fellow Americans, if the 21 st century is to be the century of biology, let us make an AIDS vaccine its first great triumph."220 It remains to be seen how this triumph will be accomplished. One thing, however, is certain: The biomedical breakthroughs that President Clinton envisions will only be achieved if those who put their lives on the line in the fight against AIDS are adequately protected against physical and social harms.

218. I agree with the UNAIDS guidance on this point: "In addition to compensation for biological/medical injuries, appropriate consideration should be given to compensation for social or economic harms, e.g., job loss as a result of testiug positive following vaccine administration." UNAIDS, supra note 70, at 12.

219. Ellis, supra note 119, at 1963.

220. President William J. Clinton, Remarks at the Morgan State University Commencement Ceremony in Baltimore, Maryland, 33 WEEKLY COMP. PRES. Doc. 727 (May 26, 1997). On President Clinton's call for an effective vaccine within a decade, see Andrew Lawler, A Deadline for an AIDS Vaccine, 276 SCIENCE 1184, 1184-85 (1997); Alison Mitchell, Clinton Calls for AIDS Vaccine as Goal, N.Y. Trmes, May 19, 1997, at A15; Charles Petit, Clinton's 10-Year Vaccine Goal Leaves AIDS Experts Skeptical, S.F. CHRON., May 20, 1997, at A2. 